\title{
Government Debt
}

\section{Citation}

Elmendorf, Douglas W., and N. Gregory Mankiw. 1999. Government Debt. In (J. B. Taylor \& M. Woodford (ed.)) Handbook of Macroeconomics 1, part 3: 1615-1669.

\section{Published Version}

http://dx.doi.org/10.1016/S1574-0048(99)10038-7

\section{Permanent link}

http://nrs.harvard.edu/urn-3:HUL.InstRepos:2643866

\section{Terms of Use}

This article was downloaded from Harvard University's DASH repository, and is made available under the terms and conditions applicable to Other Posted Material, as set forth at http:// nrs.harvard.edu/urn-3:HUL.InstRepos:dash.current.terms-of-use\#LAA

\section{Share Your Story}

The Harvard community has made this article openly available.

Please share how this access benefits you. Submit a story.

Accessibility 


\title{
Government Debt
}

\author{
Douglas W. Elmendorf \\ Federal Reserve Board \\ N. Gregory Mankiw \\ Harvard University and NBER
}

January 1998

This paper was prepared for the Handbook of Macroeconomics. We are grateful to Michael Dotsey, Richard Johnson, David Wilcox, and Michael Woodford for helpful comments. The views expressed in this paper are our own and not necessarily those of any institution with which we are affiliated. 
Abstract

This paper surveys the literature on the macroeconomic effects of government debt. It begins by discussing the data on debt and deficits, including the historical time series, measurement issues, and projections of future fiscal policy. The paper then presents the conventional theory of government debt, which emphasizes aggregate demand in the short run and crowding out in the long run. It next examines the theoretical and empirical debate over the theory of debt neutrality called Ricardian equivalence. Finally, the paper considers the various normative perspectives about how the government should use its ability to borrow.

JEL Nos. E6, H6 


\section{Introduction}

An important economic issue facing policymakers during the last two decades of the twentieth century has been the effects of government debt. The reason is a simple one: The debt of the U.S. federal government rose from 26 percent of GDP in 1980 to 50 percent of GDP in 1997. Many European countries exhibited a similar pattern during this period. In the past, such large increases in government debt occurred only during wars or depressions. Recently, however, policymakers have had no ready excuse.

This episode raises a classic question: How does government debt affect the economy? That is the question that we take up in this paper. It will not surprise the reader to learn that macroeconomists are divided on the answer. Nonetheless, the debates over government debt are fascinating and useful to study. They are fascinating because they raise many fundamental questions about economic behavior. They are useful to study because learning the sources of disagreement can help an impartial observer reach a judgment of his own.

Our survey of the effects of government debt is organized as follows. Section I considers some of the data on government debt. These data give some sense of the history of government debt in the United State and elsewhere. This section also discusses some recent projections for the beginning of the twenty-first century.

Section II then examines the conventional view of the effects of government debt. We call this view "conventional" because it is held by most economists and almost all policymakers. According to this view, the issuance of government debt stimulates aggregate demand and economic growth in the short run but crowds out capital and reduces national income in the long run. Section II turns to an alternative view of government debt, called Ricardian equivalence. According to this view, the choice between debt and 
tax finance of government expenditure is irrelevant. This section discusses the basis of this idea, its history and importance, and the debate over its validity.

Section IV moves from positive to normative analysis. It considers various perspectives on the question of how the government should use its ability to borrow. The discussion highlights the potential significance of countercyclical fiscal policy, optimal national saving, and intertemporal tax smoothing.

\section{The Data}

In this section we present some basic facts about government debt and deficits in the United States and other countries. We give the official data, and then examine a number of issues regarding the appropriate measurement of fiscal policy. We conclude the section by considering projections of future fiscal policy in a number of countries.

\section{A. Debt and Deficits in the United States and Other Countries}

We begin with data from the United States. Panel A of Figure 1 shows

U.S. federal debt as a percentage of gross national product over the past 200 years. ${ }^{1}$ It is common to exclude the debt of state and local governments, as we do, although for many purposes it is more appropriate to consider the consolidated debt of all levels of government. Most state governments hold positive net assets, because they are prohibited from running deficits in their operating budgets, and because the assets they accumulate to fund

${ }^{1}$ We take GNP data from Berry (1978, table 1B) for 1791 to 1868 , from Romer (1989) for 1869 to 1928, and from the National Income and Product Accounts since 1929. The end-of-year debt comes from Bureau of the Census (1975, series Y493) for 1791 to 1939, from Congressional Budget Office (1993, table A-2) for 1940 to 1961, and from CBO (1997a, table F-4) since 1962. We splice the series multiplicatively at the break points and convert debt from fiscal-year to calendar-year form. 
employee pensions exceed the debt they issue to finance capital projects. The figure shows federal debt "held by the public," which includes debt held by the Federal Reserve System but excludes debt held by other parts of the federal government, such as the social security trust fund.

The primary cause of increases in the U.S. debt-output ratio has been wars: The War of 1812, the Civil War, World War I, and World War II all produced noticeable upswings in federal indebtedness. The Great Depression and the 1980s are only two peacetime intervals when this ratio increased significantly. Between these sharp increases, the debt-output ratio has generally declined fairly steadily. An important factor behind the dramatic drop between 1945 and 1975 is that the growth rate of GNP exceeded the interest rate on government debt for most of that period. Under such circumstances, the government can collect taxes equal to only its non-interest spending, finance the interest payments on the outstanding debt by issuing more debt, and still watch its debt grow more slowly than the economy. This situation has potentially important implications for the effect of government debt, as we discuss later.

Panel B of Figure 1 shows the U.S. federal budget deficit as a share of GNP over the past 200 years. ${ }^{2}$ These deficit numbers are for the so-called "unified budget," which includes both "on-budget" items like national defense and "off-budget" items like Social security, thus capturing essentially all of the fiscal activities of the federal government. Once again, the effect of wars is quite apparent. The small deficits between 1955 and 1975 were consistent with a declining debt-output ratio for the reason just mentioned:

\footnotetext{
${ }^{2}$ The budget surplus comes from Bureau of the Census (1975, series Y337) for 1791 to 1928, from Bureau of the Census (1975, series Y341) for 1929 to 1961, and from CBO (1997a, table F-4) since 1962. We convert these numbers from a fiscal-year basis to a calendar-year basis. Note that the deficit does not equal the annual change in federal debt. Roughly speaking, the change in debt reflects the government's cash outlays and receipts, while the unified deficit involves a limited amount of capital budgeting. We return to this issue below.
} 
Although the debt was growing, output was growing faster. After 1975, larger deficits and a less favorable relationship between the interest rate and the growth rate caused the debt-output ratio to rise.

Government debt and deficits in other industrialized countries span a wide range, as shown in Table 1. The first column presents general government net financial liabilities as a percentage of GDP. This measure differs in several respects from that shown in panel A of Figure 1: It includes all levels of government, nets out financial assets where the data are available, and normalizes by GDP rather than GNP. Nevertheless, the U.S. value for 1996 matches the last point shown the figure. The second and third columns show the budget surplus and primary budget surplus as percentages of GDP. The primary surplus equals taxes less all non-interest spending. The highest reported debt-income ratios are in Italy and Belgium; their high debt service payments induce substantial budget deficits despite primary budget surpluses.

\section{B. Measurement Issues}

The official U.S. data on federal government debt and deficits obscure a number of interesting and important issues in assessing fiscal policy. We now discuss some of these measurement issues.

\section{Adjusting for Economic Conditions}

Official data on debt and deficits are often adjusted to reflect three economic variables: the price level, interest rates, and the business cycle. The adjustment for the price level occurs because the real value of the debt is, for many purposes, more important than the nominal value. For the level of the debt, the price-level adjustment is obvious: If $D$ is the debt and $P$ is the price level, then the real debt is $D / P$. For the deficit, however, the price-level adjustment is somewhat more subtle. It is natural to define the 
real deficit to be the change in the real value of the debt. In this case, the real deficit equals the nominal deficit (deflated by the price level) minus the inflation rate times the existing debt. That is, $d(D / P) / d t=(d D / d t) / P-[(d P / d t) / P](D / P)$

The inflation correction, which is represented by the second term on the right-hand side of this equation, can be large when inflation is high or the outstanding debt is large. Indeed, it can turn a nominal budget deficit into a real budget surplus.

The second adjustment is for the level of interest rates. The adjustment arises because the market value of the debt may be more important than the par value. When interest rates rise, outstanding debt falls in value, and when interest rates fall, the opposite occurs; of course, a given rate change will cause debt with a longer maturity to be revalued more than shorter-term debt. The market value of U.S. debt over time can be calculated using the data and procedures outlined in Seater (1981), Butkiewicz (1983), and Cox and Hirschhorn (1983). The annual change in the market value can differ noticeably from the annual change in the par value, but the series follow the same broad trends.

The third common adjustment to the budget deficit is for business cycle conditions. Because the deficit rises automatically when economic activity slows, and vice versa, the budget deficit in a given year may offer a misleading impression of underlying fiscal policy. The "standardized employment deficit" (CBO, 1997a) eliminates the effects of the business cycle on the budget. This deficit is based on estimates of what spending and revenue would be if the economy were operating at normal levels of unemployment and capacity utilization.

2. Assets and Liabilities Beyond the Official Debt Debt held by the public is the largest explicit liability of the federal 
government, but it is not the only liability. Moreover, the federal government also holds significant assets. As emphasized by Eisner and Pieper (1984) and Eisner (1986), all of these assets and liabilities should be considered in any overall accounting of the government's financial situation. Unfortunately, it is quite difficult to assess the value of many government assets and liabilities.

Some valuation problems are primarily technical. For example, a large share of the government's physical capital is defense-related, and many of these goods are not sold in (legal) markets. As another example, federal insurance of bank deposits may prove to be either very costly to the government or very inexpensive, and it is difficult to assess the probabilities of the alternative outcomes.

Other valuation problems are more conceptual. Do the future Social Security benefits specified by current law constitute a government liability in the same sense as explicit debt? The answer to this question depends at least partly on how the liability is perceived by households. If households believe that these benefits will be paid with the same probability that the explicit debt will be honored, then it may be sensible to count the present value of the benefits as government debt. In this specific case, the additional debt could be roughly three times the explicit debt, as Feldstein (1996a) estimates the present value of Social security benefits less taxes for current adults at roughly \$11 trillion in 1995. Similar questions arise for civil service and military retirement benefits, Medicare, and other entitlement programs. The important general point is that the appropriate measure of government indebtedness largely depends on peoples' behavior. As a result, deciding what measure of fiscal policy is best requires taking a stand on the correct model of economic behavior.

Attempts to measure a range of explicit government assets and liabilities include the presentations of historical federal balance sheets by 
Eisner (1986), Bohn (1992), and the Office of Management and Budget (1996). OMB's estimates for 1995 are summarized in Table 2. The largest liabilities are debt held by the public (excluding the Federal Reserve) and expected pension liabilities for federal military and civilian employees. OMB also includes the expected cost of contingent liabilities that arise from loan guarantees and insurance programs. The federal government's financial assets include gold and loans owed to the government; its physical assets include both reproducible plant and equipment (about three-quarters of which relates to national defense) and nonreproducible capital such as land and mineral deposits. OMB does not include in these estimates the cost of future social Security payments and other "continuing commitments," arguing that the appropriate way "to examine the balance between future Government obligations and resources is by projecting ... total receipts and outlays" (p. 20).

As it turns out, OMB estimates the government's assets to be worth roughly as much as its non-debt liabilities in 1995, so net explicit liabilities are close to the value of debt. Indeed, net liabilities appear to have followed debt fairly closely in recent decades, despite sometimes significant differences in their annual changes. Debt increased by about $\$ 2.4$ trillion between 1975 and 1995, while OMB estimates that liabilities rose about \$2.6 trillion. Yet, these measures diverged sharply before 1975. Bohn estimates that the net worth of the federal government was roughly the same share of GNP in 1975 as in 1947, as a dramatic decline in the debt share was offset by a drop in military assets and a rise in government employee pension obligations.

\section{Capital Budgeting}

One way to incorporate some government assets into the regular budget process is to create separate capital and operating budgets. In this way, current outlays would include not the acquisition of capital goods, but the 
depreciation of previously purchased capital. One effect of capital budgeting is that it would allow the government to spend money on capital assets without running an explicit deficit. Some observers view this situation as an inducement to profligate spending, particularly because it is difficult to decide exactly what constitutes capital, and many types of spending could acquire that label. For whatever reason, the U.S. federal government (unlike many state governments) does not rely on a capital budget as a central element of its budget process. Nevertheless, the principle of capital budgeting does affect budget numbers in two ways.

First, the unified budget includes some specific kinds of capital budgeting. Since 1992, for example, government credit programs have been counted not in terms of their current outlays, but in terms of the present value of their expected future outlays. Thus, the deficit cost of a direct student loan is not the loan amount itself, but the net cost of providing the loan, taking into account the probability of default. Because the government's cash outlays reflect the total amount of the loan, the increase in the debt exceeds the deficit. A similar pattern is repeated for some other fiscal activities where the budget amounts differ from the contemporaneous cash outlays or receipts. ${ }^{3}$

Second, the federal budget as recorded in the National Income and Product Accounts does treat government consumption and investment in physical capital differently. ${ }^{4}$ Government consumption includes an estimate of the depreciation of government capital, and government purchases of new capital

${ }^{3}$ Formally, the change in debt equals the deficit less so-called "other means of financing." Much of this category consists of short-term differences between the deficit and borrowing needs, but some other means of financing (such as direct student loans) involve quite long-term divergences.

${ }^{4}$ This treatment in the National Income and Product Accounts was introduced in 1996. There are a number of other discrepancies between unified budget principles and NIPA budget principles. These include geographic differences, timing conventions, and some shifting of items between the revenue and expenditure sides of the budget. 
are tallied separately. The federal government's investment in physical capital is fairly modest, with gross investment less than fifteen percent of consumption expenditures in 1994 .

\section{Generational Accounting}

One prominent alternative to standard debt and deficit accounting is "generational accounting," proposed by Auerbach, Gokhale, and Kotlikoff (1991) and Kotlikoff (1992). These authors argue that the conventional deficit and explicit debt "simply reflect economically arbitrary labeling of government receipts and payments," so that the measured deficit "need bear no relationship to the underlying intergenerational stance of fiscal policy" (p. 56). Generational accounts measure fiscal policy by its impact on different generations, not by the annual flows of spending and taxes.

Generational accounts are constructed by extrapolating current policies through the lifetimes of all people currently alive, and calculating the net taxes they would pay under those policies. The net taxes of future generations are then set at a level which satisfies the government's intertemporal budget constraint. These calculations provide important information about how fiscal policy redistributes resources across generations. For example, most of the transfer from young to old during the postwar period occurred not in the $1980 \mathrm{~s}$ when measured deficits were high, but between the 1950s and 1970s when deficits were low but social security benefits were being enhanced.

Nevertheless, generational accounts do suffer from some problems, as explored by Cutler (1993) and Congressional Budget Office (1995). One set of problems involves technical issues in constructing the accounts. For example, it is unclear what is the appropriate discount rate for future taxes, and different discount rates produce very different quantitative results. A 
second issue is whether the labelling of government receipts and payments truly is arbitrary. For instance, the methodology of generational accounting treats Social Security payments and interest payments on government debt as essentially equivalent. Yet it is surely easier for the government to reduce future Social Security benefits than to reduce future coupon payments on existing debt securities. The label "government debt" appears to have some true meaning.

A final important problem springs from the fact that generational accounting is inextricably tied to a specific model of individual behavior. In particular, the methodology assumes that people are life-cycle consumers without a bequest motive, so that their behavior and well-being depend on their assessment of government policies over their entire lifetimes and only over their lifetimes. If individuals are liquidity-constrained or myopic, however, then their behavior and well-being may be more sensitive to current taxes than to the present value of the future taxes they expect to pay. Conversely, if individuals have altruistic bequest motives (a possibility we discuss extensively later), then their behavior and well-being will be sensitive to future taxes that will be paid by their descendants. In either case, generational accounts fail to provide a good gauge of fiscal policy for either positive or normative purposes.

\section{Future Fiscal Policy}

Current patterns of taxes and spending are unsustainable in most industrialized countries over the next twenty-five years. The primary causes of this situation are the aging of their populations and the rising relative cost of medical care. Table 3 presents the elderly dependency ratio--defined as the population age 65 and over as a percentage of the population ages 20 to 64--for a number of countries. Between 1990 and 2030, longer lifespans and continued low birthrates will sharply increase the ratio of retirees to 
working adults. The U.S. population is projected to age less dramatically than the population of many other industrialized countries, but the increase in retirees per worker in the United States is still expected to exceed 50 percent.

In most countries, health care has absorbed an increasing share of national income over the past several decades. The cost of producing most specific medical services may not have increased, but the cost of providing medical care that meets the social standard clearly has risen. Predicting future developments in this area is difficult, but most analysts expect the relative cost of medical care to continue to increase for some time.

A large share of government outlays involves transfers from working adults to retirees or the financing of health care. (Of course, these categories overlap heavily.) Thus, the aging of the population and the increasing cost of health care will put a significant strain on government finances over the coming decades. Table 4 shows projections for the effect of population aging on various countries' budget surpluses and debts under the assumption that current tax and spending rules remain unchanged. The numbers show only the direct effect of aging, and ignore the problem of paying interest on the accumulating debt. The projections are highly uncertain as well. Nevertheless, they show a marked deterioration in the fiscal situation of almost every country.

For the United States, the Congressional Budget Office (CBO, 1997b) has performed a careful analysis of the fiscal outlook. The analysis incorporates the need to pay interest on the accumulating debt, as well as the feedback between debt and the economy. Table 5 summarizes CBO's results. Without economic feedbacks, government debt more than doubles as a share of output by 2030; including feedbacks, this share rises three-fold. A large part of this looming fiscal problem is the expected rise in future payments for social Security and Medicare. Dealing with this long-term fiscal imbalance will 
likely be one of the most significant challenges facing policymakers during the next century.

\section{The Conventional View of Debt}

In this section we present what we believe to be the conventional view of the effects of government debt on the economy. We begin with a qualitative description of those effects, focusing on the impact of debt on saving and capital formation, and thereby on output and income, on factor prices and the distribution of income, and on the exchange rate and foreign transactions. We also review some other economic and non-economic consequences of government borrowing.

Following our qualitative analysis, we try to quantify some of the longrun effects of debt in a very rough way. Although quantifying these effects precisely is an arduous task, we think it important to have some quantitative sense of what is at stake. Therefore, we present a ballpark estimate of the impact of debt, which is interesting in itself and also illuminates some of the critical assumptions underlying all quantitative analyses of government debt.

Our analysis assumes that government spending on goods and services is not affected by debt policy. That is, we examine the effects of issuing a given amount of debt and reducing taxes temporarily by an equal amount. Because the government must satisfy an intertemporal budget constraint, and because debt cannot grow forever as a share of income, this temporary tax reduction will generally be accompanied by a future tax increase. For most of this section, we simply assume that the present value of that tax increase equals the current increase in debt. We defer more careful consideration of the budget constraint to the last part of the section, where we re-examine the effects of debt in a world with uncertainty. The analysis also assumes, except where stated otherwise, that monetary policy is unaffected by debt 
policy. By excluding possible monetization of the debt, we can couch our discussion in real, rather than nominal, terms.

\section{A. How Does Debt Affect the Economy?}

The government's debt policy has important influence over the economy both in the short run and in the long run. We begin by discussing the shortrun effects of budget deficits. We then turn to the long-run effects, of which the most important is a reduction in national wealth. In particular, we explain both how deficits affect national saving and how the change in saving affects many aspects of the economy. We also consider several other long-run effects of government debt.

\section{The Short Run: Increased Demand for Output}

Suppose that the government creates a budget deficit by holding spending constant and reducing tax revenue. This policy raises households' current disposable income and, perhaps, their lifetime wealth as well. Conventional analysis presumes that the increases in income and wealth boost household spending on consumption goods and, thus, the aggregate demand for goods and services.

How does this shift in aggregate demand affect the economy? According to conventional analysis, the economy is Keynesian in the short run, so the increase in aggregate demand raises national income. That is, because of sticky wages, sticky prices, or temporary misperceptions, shifts in aggregate demand affect the utilization of the economy's factors of production. This Keynesian analysis provides a common justification for the policy of cutting taxes or increasing government spending (and thereby running budget deficits) when the economy is faced with a possible recession. Conventional analysis also posits, however, that the economy is classical in the long run. The sticky wages, sticky prices, or temporary 
misperceptions that make aggregate demand matter in the short run are less important in the long run. As a result, fiscal policy affects national income only by changing the supply of the factors of production. The mechanism through which this occurs is our next topic.

\section{The Long Run: Reduced National Saving and Its Consequences}

To understand the effect of government debt and deficits, it is crucial to keep in mind several national accounting identities. Let $Y$ denote national income, $C$ private consumption, $S$ private saving, and $T$ taxes less government transfer payments. The private sector's budget constraint implies that:

$$
Y=C+S+T \text {. }
$$

National income also equals national output, which can be divided into four types of spending:

$$
Y=C+I+G+N X,
$$

where $I$ is domestic investment, $G$ is government purchases of goods and services, and $N X$ is net exports of goods and services. Combining these identities yields:

$$
S+(T-G)=I+N X \text {. }
$$

This identity states that the sum of private and public saving must equal the sum of investment and net exports.

The next important identity is that a nation's current account balance must equal the negative of its capital account balance. The current account balance is defined as net exports $N X$ plus net investment income by domestic residents and net transfers; for the most part, we ignore these last two, smaller pieces. The negative of the capital account balance is called net foreign investment, or NFI, which is investment by domestic residents in other countries less domestic investment undertaken by foreign residents. Thus, the third identity is simply: 


$$
N X=N F I,
$$

so that international flows of goods and services must be matched by international flows of funds. Substituting this identity into the other two identities yields:

$$
S+(T-G)=I+N F I .
$$

The left side of this equation shows national saving as the sum of private and public saving, and the right side shows the uses of these saved funds for investment at home and abroad. This identity can be viewed as describing the two sides in the market for loanable funds.

Now suppose that the government holds spending constant and reduces tax revenue, thereby creating a budget deficit and decreasing public saving. This identity may continue to be satisfied in several complementary ways: Private saving may rise, domestic investment may decline, and net foreign investment may decline. We consider each of these possibilities in turn.

To start, an increase in private saving may ensue for a number of reasons that we discuss below. In fact, some economists have argued that private saving will rise exactly as much as public saving falls, and the next section of the paper examines this case at length. For now, we adopt the conventional view that private saving rises by less than public saving falls, so that national saving declines. In this case, total investment--at home and abroad--must decline as well.

Reduced domestic investment over a period of time will result in a smaller domestic capital stock, which in turn implies lower output and income. With less capital available, the marginal product of capital will be higher, raising the interest rate and the return earned by each unit of capital. At the same time, labor productivity would be lower, thereby reducing the average real wage and total labor income.

Reduced net foreign investment over a period of time means that domestic residents will own less capital abroad (or that foreign residents will own 
more domestic capital). In either case, the capital income of domestic residents will fall. Moreover, the decline in net foreign investment must be matched by a decline in net exports, which constitutes an increase in the trade deficit of goods and services. As this connection between the budget deficit and the trade deficit became better known in the United States during the 1980s, it led to the popular term "twin deficits." Pushing the trade balance into deficit generally requires an appreciation of the currency, which makes domestically-produced goods relatively more expensive than foreignproduced goods. ${ }^{5}$

\section{Other Effects}

Although increasing aggregate demand in the short run and reducing the capital stock in the long run are probably the most important effects of government budget deficits, debt policy also affects the economy in various other ways. We describe several of these effects here.

First, government debt can affect monetary policy. A country with a large debt is likely to face high interest rates, and the monetary authority may be pressured to try to reduce those rates through expansionary policy. This strategy may reduce interest rates in the short run, but in the long run will leave real interest rates roughly unchanged and inflation and nominal interest rates higher. In the United States, at least in recent years, monetary policy has apparently not responded to fiscal policy in this way. For example, the U.S. debt-income ratio rose sharply during the 1980s, and the U.S. inflation rate declined sharply. Nevertheless, successive Chairmen of the Federal Reserve Board have warned of the possible link between the budget

${ }^{5}$ For more complete analysis of the international effects of debt, see Frenkel and Razin (1992, chapters 7, 8, 10 and 11) and Obstfeld and Rogoff (1996, chapter 3). 
deficit and inflation. ${ }^{6}$

In extreme cases, a country with a large debt may have difficulty financing an ongoing deficit through additional borrowing and, as a result, will be tempted to raise revenue through seigniorage. If the fiscal authority can force the monetary authority to finance ongoing deficits with seigniorage, then, as Sargent and Wallace (1981) argue, inflation is ultimately a fiscal phenomenon rather than a monetary one. ${ }^{7}$ This monetization of the debt is the classic explanation for hyperinflation. For example, staggering budget deficits as a share of national income were the root cause of hyperinflations in 1920s Germany and 1980s Bolivia. As Sargent (1983) explains, inflation can fall sharply in such a country when government borrowing is reduced and the central bank commits not to finance future deficits. Yet, this line of reasoning is not very important for most developed countries today, as seigniorage represents a very small share of total government revenue. ${ }^{8}$ A second effect of government debt is the deadweight loss of the taxes needed to service that debt. The debt-service payments themselves are not a

\footnotetext{
${ }^{6}$ Paul Volcker told Congress in 1985 that "the actual and prospective size of the budget deficit ... heightens skepticism about our ability to control the money supply and contain inflation" (p. 10). Alan Greenspan said in 1995 that he expected that "a substantial reduction in the long-term prospective deficit of the United States will significantly lower very long-term inflation expectations vis-a-vis other countries" (p. 141).

${ }^{7}$ Woodford (1995) proposes an alternative "fiscal theory of the price level," based on the effect of prices on the real value of government debt and thus on aggregate demand. Woodford considers an economy of infinitely-lived households, and hypothesizes an increase in government debt with no offsetting change in future taxes or spending. This policy makes households wealthier and increases aggregate demand. If aggregate supply is unchanged, both goodsmarket equilibrium and the government's budget constraint require that the price level increases enough to reduce real debt to its initial value. The mechanism is quite similar to the Pigou-Patinkin (1965) real-balance effect, except that it allows for households that appear to be Ricardian, and it involves total government liabilities rather than just outside money. In contrast to the Sargent-Wallace analysis, Woodford's point does not depend on any particular response by the monetary authority to changes in fiscal policy.

${ }^{8}$ For further analysis of the connections between fiscal policy and monetary policy, see Aiyagari and Gertler (1985), Leeper (1991), McCallum (1984), and Sims (1994).
} 
cost to a society as a whole, but, leaving aside any payments to foreigners, merely a transfer among members of the society. Yet effecting that transfer in a world without lump-sum taxes will create some distortion of individual behavior that generates a deadweight loss. Thus, a policy of reducing taxes and running a budget deficit means smaller deadweight losses as the debt is being accumulated but larger deadweight losses when the debt is being serviced with higher taxes.

A third effect of government debt is to alter the political process that determines fiscal policy. Some economists have argued that the possibility of government borrowing reduces the discipline of the budget process. When additional government spending does not need to be matched by additional tax revenue, policymakers and the public will generally worry less about whether the additional spending is appropriate. This argument dates back at least to Wicksell (1896), and has been echoed over the years by Musgrave (1959), Buchanan and Wagner (1977), and Feldstein (1995) among others. Wicksell claimed that if the benefit of some type of government spending exceeded its cost, it should be possible to finance that spending in a way that would receive unanimous support from the voters; he concluded that the government should only undertake a course of spending and taxes that did receive nearly unanimous approval. In the case of deficit finance, Wicksell was concerned that "the interests [of future taxpayers] are not represented at all or are represented inadequately in the tax-approving assembly" (p. 106). Musgrave noted that when budget balance is altered for stabilization purposes, "the function of taxes as an index of opportunity cost [of government spending] is impaired" (p. 522). Buchanan and Wagner asserted that a balanced-budget rule "will have the effect of bringing the real costs of public outlays to the awareness of decision makers; it will tend to dispel the illusory 'something for nothing' aspects of fiscal choice" (p. 178). And Feldstein wrote that "only the 'hard budget constraint' of having to balance the budget" can force 
politicians to judge whether spending's "benefits really justify its costs" (p. 405$)$.

It is also possible that the existence of government debt reduces the fiscal flexibility of the government. If moderate levels of debt have only small negative effects, but larger debts are perceived to be quite costly, then a country with a moderate debt will be constrained from responding to calls for greater spending or lower taxes. This constraint on future policymakers is, in fact, one of the explanations sometimes given for why governments choose to accumulate large debts.

A fourth way in which government debt could affect the economy is by making it more vulnerable to a crisis of international confidence. The Economist (4/1/95) noted that international investors have worried about high debt levels "since King Edward III of England defaulted on his debt to Italian bankers in 1335" (p. 59). During the early 1980s, the large U.S. budget deficit induced a significant inflow of foreign capital and greatly increased the value of the dollar. Marris (1985) argued that foreign investors would soon lose confidence in dollar-denominated assets, and the ensuing capital flight would sharply depreciate the dollar and produce severe macroeconomic problems in the United States. As Krugman (1991) described, the dollar did indeed fall sharply in value in the late 1980s, but the predicted "hard landing" for the U.S. economy did not result. Krugman emphasized, however, that currency crises of this sort have occurred in countries with higher debtoutput ratios, particularly when much of that debt is held by foreigners, as in many Latin American countries in the 1980s.

A fifth effect of government debt is the danger of diminished political independence or international leadership. As with the danger of a hard landing, this problem is more likely to arise when government borrowing is large relative to private saving and when the country experiences a large capital inflow from abroad. Friedman (1988) asserted: "World power and 
influence have historically accrued to creditor countries. It is not coincidental that America emerged as a world power simultaneously with our transition from a debtor nation ... to a creditor supplying investment capital to the rest of the world" (p. 13).

\section{B. How Large is the Long-Run Effect of Debt on the Economy?}

So far we have described the effects of government debt in qualitative terms. We now present rough quantitative estimates of some of these effects. We begin with an extremely simple calculation of the effect on national income of a reduced capital stock, and we then explore the sensitivity of our results to three key assumptions. Our ballpark estimate is, in fact, broadly consistent with the few other quantitative analyses in the literature. We also note the magnitude of the deadweight loss caused by the taxes needed to finance the debt service. We calibrate our calculations for the U.S. economy, but the approach is applicable to other countries as well.

\section{The Parable of the Debt Fairy}

As we have discussed, a primary effect of government debt is the crowding out of capital and the consequences that result from this crowding out. How large are these effects? To answer this question, consider the parable offered by Ball and Mankiw (1995). Imagine that one night a debt fairy (a cousin of the celebrated tooth fairy) were to travel around the economy and replaced every government bond with a piece of capital of equivalent value. How different would the economy be the next morning when everyone woke up?

It is straightforward to calculate the effect of this addition to the capital stock. If factors of production earn their marginal product, then the marginal product of capital equals the capital share of income (MPK*K/Y) divided by the capital-output ratio (K/Y). In the United States between 1960 
and 1994, the gross return to capital was roughly one-third of income, and the capital-output ratio averaged a little over three. ${ }^{9}$ The implied marginal product of capital is about 9.5 percent. More precisely, this figure represents the gross marginal product; it shows how much an extra dollar of capital adds to gross output and income. If the country wants to maintain that dollar of capital, however, then it needs to do replacement investment to offset depreciation. Depreciation amounts to roughly 3.5 percent of capital, so the net marginal product of capital is about 6 percent. In other words, each dollar of capital raises gross national product by 9.5 cents and net national product by 6 cents.

When the debt fairy magically reverses the effects of crowding out, the amount of capital increases by the amount of federal government debt, which in the United States is about one-half of gross output. Our estimates of the marginal product of capital imply that gross output would be increased by about 4.75 percent, and net output by about 3 percent. ${ }^{10}$ In 1997 , these increases amount to about $\$ 400$ billion and $\$ 250$ billion, respectively. The story of the debt fairy is appealing because it offers a simple way

${ }^{9}$ These data are drawn from the National Income and Product Accounts of the Commerce Department's Bureau of Economic Analysis (BEA). Net capital income is the sum of corporate profits, rental income, net interest, and a share of proprietors' income (all with appropriate adjustments for inventory valuation and capital consumption). Gross capital income equals net income plus depreciation. We use national income plus depreciation as the measure of total output and income. The capital stock is BEA's net stock of fixed reproducible tangible wealth excluding consumer durables. Including the value of inventories and land in the measure of capital would depress the estimated return on capital. On the other hand, Feldstein, Dicks-Mireaux, and Poterba (1983) note that "pre-tax" corporate profits in the national income accounts actually represent profits after the payment of state and local property taxes; adding these taxes back into profits would raise the estimated rates of return. Finally, some authors measure the benefit of additional saving by the return to nonfinancial corporate capital. Because corporate capital is more heavily taxed than other capital, it earns a higher pre-tax return. Yet, there is no reason to assume that any addition to the capital stock would flow disproportionately to corporations.

${ }^{10}$ The actual effect of adding this much capital would be somewhat smaller, because the marginal product would decline as the capital stock increased. 
to calculate the effects of government debt on national income. But is this calculation realistic? The debt-fairy calculation implicitly makes three assumptions:

(1) Deficits do not affect private saving, so debt crowds out other forms of private wealth one for one.

(2) The economy is closed, so crowding out takes the form of a reduced capital stock

(3) The profit rate measures the marginal product of capital, so it can be used to gauge the effects of a change in the capital stock.

Let us consider how relaxing each of these assumptions might alter the conclusion that current U.S. government debt reduces U.S. national income by about 3 percent.

\section{A Closer Look at the Effect of Debt on Private Savings}

The debt fairy replaces each dollar of government debt with one dollar of capital. Is this dollar-for-dollar substitution appropriate? More concretely, if the U.S. government had run sufficient surpluses during the past twenty years to reduce its debt to zero, would national wealth now be larger by the amount of the actual current debt?

In actuality, an increased flow of government borrowing will affect the flow of private saving through several channels. First, private saving will rise because some households will save part of the tax reduction to consume later in life. Second, forward-looking consumers will realize that the increasing debt will force higher future interest payments by the government and, thus, higher future taxes. Third, greater government borrowing will affect interest rates and wages, and these general-equilibrium effects in turn will affect private saving. Fourth, the government's debt policy may affect distortionary capital taxes, which in turn affect private saving. For all of these reasons, the size of the budget deficit affects the amount of private 
saving.

Understanding the long-run effect of debt on capital therefore requires a formal, general equilibrium model, with particular attention paid to household saving behavior. Conventional analysis focuses on models with overlapping generations of life-cycle consumers introduced by Samuelson (1958) and Diamond (1965). Because this model incorporates people at different stages of their life-cycle who differ in both their level of wealth and marginal propensity to consume out of wealth, aggregation is often difficult in realistic models with more than two generations. Blanchard (1985) resolves this problem by making assumptions about the aging process that simplify aggregation analytically. Auerbach and Kotlikoff (1987) and other researchers resolve this problem by simulating a more complicated model numerically. Before turning to the results from these well-known analyses, however, it is instructive to examine a simple, stylized example. Consider an economy in which every person lives for a fixed number of periods. Assume that the interest rate is given (either because this is a small open economy or because the technology is linear in capital and labor). Also assume that the consumers choose the same level of consumption in each period of life (either because their rate of time preference happens to equal the interest rate or because they have Leontief preferences). Now consider how an increase in government debt affects the steady state. Higher debt means higher interest payments and higher taxes. If those taxes are distributed equally across people of different ages, then each person's after-tax income is reduced by the amount of those interest payments (per capita) in each period. Because consumers still want to smooth consumption, they respond to this higher tax burden by reducing consumption in each period by the same amount. As a result, after-tax income and consumption fall equally, private saving is unchanged, and private wealth is unchanged. Each dollar of debt crowds out exactly one dollar of capital, as assumed by the debt fairy parable. 
To see what happens when various assumptions are relaxed, we turn to the Blanchard and Auerbach-Kotlikoff analyses. Blanchard develops a continuoustime overlapping-generations model in which people have log utility and face a fixed probability of dying in each period. He examines the effect of accumulating additional government debt and then holding debt at its new level forever. To establish notation, let $D$ denote debt and $W$ denote national wealth (domestic capital plus net foreign assets), so private wealth equals $D+W$. For a small open economy, Blanchard confirms the result from our simple example: Steady-state $d W / d D$ equals -1 if the rate of time preference equals the world interest rate. If the world interest rate and the rate of time preference differ, crowding out may be larger or smaller than one for one. ${ }^{11}$ Matters become more complicated in a closed economy. In this case, as capital is crowded out, the interest rate rises, and households are encouraged to save. As a result, the absolute value of $d W / d D$ is smaller in a closed economy than in an open economy. ${ }^{12}$ Calculations using the Blanchard model indicate that the difference between open and closed economies is substantial, but this result appears highly sensitive to the assumption of log utility, according to which households are very willing to substitute consumption between periods in response to a higher interest rate. Most research in the consumption literature suggests a much smaller intertemporal elasticity of substitution than unity. ${ }^{13}$

\footnotetext{
${ }^{11}$ Let $p$ be the probability of dying in each period or, as suggested by Blanchard and Summers (1984), a "myopia coefficient" that reflects mortality or myopia. Let $r$ equal the world interest rate and 2 the rate of time preference. Then Blanchard reports that $d W / d D=-p(p+r)^{-1}(p+2)(p+2-r)^{-1}$.

${ }^{12}$ Blanchard and Fischer (1989, p. 131) report that, in the steady state, $d K / d D=-p(p+2) /\left[(p+r)(p+2-r)-F^{\prime C} C\right.$, where $K$ is the capital stock, $C$ is consumption, and $\mathrm{F}$ is the aggregate net production function.

${ }^{13}$ For attempts to use variants of the Blanchard model to estimate the cost of various debt policies, see Romer (1988) and Evans (1991).
} 
Auerbach and Kotlikoff (1987) construct a large-scale general equilibrium model, and simulate the model to examine the effects of alternative debt, tax, and Social security policies. The numerical simulations reveal not only the steady-state changes in capital and other variables, but also the transition path to the new steady state. The model assumes that people have an economic lifetime of 55 years, have perfect foresight about future economic conditions, and make rational choices regarding their consumption and labor supply. The government raises funds through distortionary taxes and satisfies an intertemporal budget constraint. A production function for net output completes the model, which describes a closed economy. Auerbach and Kotlikoff choose values for the key parameters based on the empirical literature. Note, in particular, that they assume that the intertemporal elasticity of substitution is 0.25 .

Auerbach and Kotlikoff examine the effect of reducing taxes and accumulating debt over a certain number of years, and then boosting taxes to hold the debt at its new per-capita level forever. This debt policy reduces saving and capital by transferring resources from younger and future generations, who have a low or zero marginal propensity to consume, to older generations, who have a high marginal propensity to consume. Capital is also diminished by the higher rate of distortionary income taxes in the long run, although the initial reduction in the tax rate can actualy crowd-in capital in the short run. Auerbach and Kotlikoff analyze deficits equal to 5 percent of output that last for one year, 5 years, and 20 years; they do not report the resulting levels of debt, but these can be calculated approximately based on the size of the deficits and the interest rate. For all three experiments, the decline in capital appears to be extremely close to the increase in 
debt. ${ }^{14}$

We conclude this discussion by emphasizing that the short-run effect of a budget deficit on consumption and saving is a poor guide to the long-run effect of debt on national wealth. In a model with life-cycle consumers, government debt may have only a small short-run effect, as confirmed by Blanchard (who finds that initial saving adjusts by only several percent of a change in debt) and Auerbach and Kotlikoff (who find that at the end of a 20year tax cut, the capital stock is reduced by only one-fifth of its eventual decline). Nonetheless, debt has a much larger effect on life-cycle consumers in the long run. Auerbach and Kotlikoff's closed-economy model shows approximately one-for-one crowding out; Blanchard's formulas suggest smaller effects in a closed economy but roughly one-for-one crowding out in an open economy. On balance, the debt fairy's one-for-one substitution of capital for debt may be on the high side of the truth, but it seems a reasonable approximation .

\section{A Closer Look at International Capital Flows}

When the debt fairy changes government debt into national wealth, the increment to national wealth is assumed to take the form of domestic capital, with no change in net ownership of foreign assets. This is clearly not a realistic description of an open economy. Yet, alternative assumptions about international capital flows would have little effect on the estimated impact of government debt.

In actuality, net international capital flows are fairly small. Feldstein and Horioka (1980) examined five-year averages of domestic investment and saving across countries and found these two variables moved

\footnotetext{
${ }^{14}$ The increases in debt from the three alternative policies are roughly 5, 30, and 200 percent of output. The corresponding declines in the capital stock are 5, 29, and 182 percent of output.
} 
almost exactly one for one with each other. More recent estimates suggest that the strength of this relationship declined somewhat in the 1980 s. Nonetheless, these estimates indicate about 75 percent of a long-term change in national saving adds to domestic investment and only 25 percent goes to investment abroad. ${ }^{15}$

Because many countries allow capital to move freely across their borders, it is surprising that net international capital flows are not larger in the long run. The literature has considered many possible explanations. ${ }^{16}$ For our purposes, though, the key point is that the existence of international capital flows--or the lack of such flows--has little impact on the ultimate cost of government debt. Suppose that the debt fairy transformed each dollar of reduced debt into an extra dollar of net foreign assets, rather than an extra dollar of domestic capital. In this case, which is the extreme opposite of our original assumption, the debt reduction would not raise domestic output at all. Instead, it would raise foreign output, and some of that output would flow back to this country as the return on our additional overseas assets. As long as the return to wealth are the same at home and abroad, the location of the extra wealth does not affect our income.

Another way to understand this point is to note the distinction between domestic income and national income. Domestic income is the value of production occurring within a nation's borders; this is identically equal to domestic output or GDP. Tomorrow's domestic output and income depend on today's domestic investment. But the consumption of domestic residents depends on their income, which is the value of production accruing to a

${ }^{15}$ See Feldstein and Bacchetta (1991) and Dornbusch (1991).

${ }^{16}$ Frankel (1991), Mussa and Goldstein (1993), and Gordon and Bovenberg (1996) review the evidence regarding international capital mobility and discuss a number of explanations for the observed immobility. For a recent attempt to explain the Feldstein-Horioka puzzle within the context of neoclassical growth theory, see Barro, Mankiw, and Sala-i-Martin (1995). 
nation's residents. This is called national income, and it is identically equal to national output or GNP. Tomorrow's national output and income depend on today's national saving, wherever this saving is ultimately invested.

Naturally, this strong statement requires several caveats. First, the statement ignores the tax implications of the location of capital. Governments receive a higher effective tax rate on capital located in their countries than on capital owned by their residents but located abroad. Thus, the social return to domestic investment is higher than the social return to foreign investment, even if the private (after-tax) returns are the same.

Second, additional capital accumulation does not reduce the marginal product of capital as quickly if the capital can flow abroad. As we saw in our earlier discussion of the Blanchard model, the effect of debt on the capital stock is reduced if changes in the capital stock affect the interest rate and thereby private saving

Third, the location of nationally-owned capital does affect the distribution of income. If the domestic capital stock increases, so does the wage, while the return to capital and the interest rate fall; domestic workers benefit and owners of domestic capital are hurt. ${ }^{17}$ An increase in the ownership of capital located abroad does not have these effects.

Fourth, international capital flows change the composition of domestic production. If a smaller deficit raises net foreign investment, then net exports will rise, while if it increases only domestic investment, then of course investment spending will rise. Moreover, the budget deficit affects the exchange rate if there are significant international capital flows, but not otherwise.

On balance, it seems that the issuance of government debt has only a small effect on international capital flows in the long run and that those

${ }^{17}$ Because some owners of domestic capital are foreigners, this shift actually raises national income slightly. 
flows have only a small effect on the return to extra saving. Acknowledging the openness of the economy, therefore, does not substantially alter the estimated impact of government debt.

\section{A Closer Look at the Marginal Product of Capital}

In describing the impact of the debt fairy, we calculated the marginal product of capital using the capital share of national income and the capitaloutput ratio. This calculation was based on the standard premise that the factors of production, including capital, are paid their marginal product. Now we reconsider whether that calculation was appropriate.

In recent years, there has been a wave of research that proposes a new view of capital. As Mankiw (1995) discusses, a variety of empirical problems with the basic neoclassical growth model would be resolved if the true capital share in the production function is much larger than the one-third measured from the national income accounts. One reason that the true capital share might be larger than the raw data suggest is that capital may have significant externalities, as argued by Romer $(1986,1987)$. If the social marginal product of capital is well above the private marginal product that we observe, then reducing government debt and raising the capital stock would have much larger effects than the debt fairy parable suggests.

Another possible reason for a large capital share is that the correct measure of capital includes human capital, such as education and training, as well as tangible physical capital, like plant and equipment. Mankiw, Romer and Weil (1992) propose an extension of the basic solow (1956) model in which there are fixed saving rates for both physical capital and human capital. They show that cross-country data are consistent with this model and an aggregate production function of the form $Y=K^{1 / 3} H^{1 / 3} L^{1 / 3}$. If the share of income devoted to human-capital accumulation is unchanged by debt policy, then the reduction in income caused by the crowding-out of physical capital will 
also reduce the stock of human capital; in this case, government debt reduces income substantially more than our earlier calculation indicated. By contrast, if the stock of human capital remained fixed, then our earlier calculation would be correct.

\section{The Deadweight Loss of Servicing the Debt}

When discussing the qualitative effects of debt, we reviewed a number of issues beyond the impact of debt on the capital stock. The only one of those effects that is readily quantifiable is the deadweight loss of the additional taxes needed to meet the debt service burden. ${ }^{18}$ of course, the deadweight loss of taxation was reduced during the period when taxes were lower and the debt was accumulated, and optimal debt policy requires balancing these effects. Our concern here, however, is just with the cost of an ongoing debt. If the government builds up a certain debt, and then decides to hold that debt constant in real terms, the additional debt service per dollar of accumulated debt is $r$, the real interest rate on debt. If 8 is the deadweight loss per dollar of tax revenue, then the loss per dollar of debt is $8 \mathrm{r}$. The total real return on intermediate-maturity government debt averaged about 2 percent between 1926 and 1994 (Stocks, Bonds, Bills and Inflation, 1995). A standard choice for 8 is Ballard, Shoven, and Whalley's (1985) estimate of one-third, although Feldstein (1996b) argues that incorporating distortions to the form of compensation and the demand for deductions--in addition to the usual distortions to labor and capital supply--makes the true 8 much larger. If 8 equals one-half, then $8 r$ is .01 , and with the U.S. debt-income ratio at one-half, the deadweight loss from servicing the debt is about half a percent of output.

\footnotetext{
${ }^{18}$ Auerbach and Kotlikoff's (1987) estimates of the welfare effects of debt policy include this cost, but isolating its significance from their published results is not possible.
} 


\section{Summary}

As concern about current and prospective U.S. budget deficits has grown, quantitative estimates of the effect of debt have begun to appear in official U.S. government documents. For example, the 1994 Economic Report of the President (pp. 85-87) assumed that the President's deficit-reduction plan would boost national saving by 1 percent of output each year for 50 years. Then the Report used a simple solow growth model to show the effect of that extra saving on the economy. It concluded that the additional saving would eventually raise output by 3.75 percent. More recently, the Congressional Budget Office (CBO, 1997b) constructed a complex model of the economy and the federal budget and simulated the model through the year 2050. Because current law would produce an explosive rise in the national debt over that period, CBO's results do not reflect steady-state effects. In the simulation that includes the economic effects of increasing debt, debt rises by 30 percent of output by 2020, resulting in output that is 2 percent smaller than it otherwise would be. Over the following decade, debt increases by another 80 percent of output, and output is diminished by more than 8 percent relative to the same baseline. Thus, these calculations are similar in spirit to those found in the academic literature.

We have now quantified, in a very rough way, some long-run effects of government debt on the economy. The debt fairy parable implied that each dollar of debt reduces net output by about six cents each year. More careful consideration of the strong assumptions embodied in that parable suggested that this estimated cost is at least in the right ballpark. The deadweight loss from the taxes needed to service the debt adds about another one cent per dollar of debt. Thus, the U.S. debt of the late 1990s, which equals about half of annual output, is reducing net output by about 3.5 percent. In 1997 , this amounts to around $\$ 300$ billion per year.

Is this cost large? Labor productivity has increased by about one 
percent per year in the United States since 1975, so reducing output by three to four percent is like giving up three to four years of productivity growth. That is a significant loss, but it does not qualify as a disaster. One final comparison of the cost of the current debt is to the effect of the upcoming demographic transition in the United States. CBO (1997b) projects that, under current law, population aging and rising health care costs will boost noninterest spending of the federal government by five percent of output between 1996 and 2025. If the current debt were maintained in real terms, it would represent about one-third of real output in 2025 (because of economic growth) . Thus, eliminating that debt would add about two percent to national income, or almost half of the extra income needed to cover the additional government spending

\section{Ricardian Equivalence}

So far our discussion has focussed on the conventional analysis of government debt. By "conventional," we mean that this analysis describes the views held by most economists and almost all policymakers. There is, however, another view of government debt that has been influential in the academic debate, even if endorsed by only a minority of economists. That view is called Ricardian equivalence after the great 19th century economist David Ricardo, who first noted the theoretical argument. In recent years, the Ricardian view has been closely associated with Robert Barro, whose work has given the view renewed vigor and prominence.

\section{A. The Idea and Its History}

Ricardian equivalence is a type of neutrality proposition: It states that a certain type of government policy does not have any important effects. In this section we discuss the general idea, its history, and its importance 
as a theoretical benchmark. In the following sections we examine the various dimensions of the debate over the validity of Ricardian equivalence as a description of the real world.

1. The Essence of the Ricardian Argument

Suppose that the government cuts taxes today without any plans to reduce government purchases today or in the future. As we have seen, conventional analysis concludes that this policy will stimulate consumption, reduce national saving and capital accumulation, and thereby depress long-term economic growth. By contrast, the theory of Ricardian equivalence asserts that this policy will not alter consumption, capital accumulation, or growth. The situation with the tax cut and budget deficit is equivalent to the situation without it.

The Ricardian argument is based on the insight that lower taxes and a budget deficit today require (in the absence of any change in government purchases) higher taxes in the future. Thus, the issuing of government debt to finance a tax cut represents not a reduction in the tax burden but merely a postponement of it. If consumers are sufficiently forward looking, they will look ahead to the future taxes implied by government debt. Understanding that their total tax burden is unchanged, they will not respond to the tax cut by increasing consumption. Instead, they will save the entire tax cut to meet the upcoming tax liability; as a result, the decrease in public saving (the budget deficit) will coincide with an increase in private saving of precisely the same size. National saving will stay the same, as will all other macroeconomic variables.

In essence, the Ricardian argument combines two fundamental ideas: the government budget constraint and the permanent income hypothesis. The government budget constraint says that lower taxes today imply higher taxes in the future if government purchases are unchanged; the present value of the tax 
burden is invariant to the path of the tax burden. The permanent income hypothesis says that households base their consumption decisions on permanent income, which depends on the present value of after-tax earnings. Because a debt-financed tax cut alters the path of the tax burden but not its present value, it does not alter permanent income or consumption. Thus, all of the predictions of the conventional analysis of government debt no longer hold. Another way to view the Ricardian argument is suggested by the title of Robert Barro's classic 1974 paper "Are Government Bonds Net Wealth?" To the owners of government bonds, the bond represents an asset. But to taxpayers, government bonds represents a liability. A debt-financed tax cut is like a gift of government bonds to those getting the tax cut. This gift makes the holder of the bond wealthier, but it makes taxpayers poorer. On net, no wealth has been created. Because households in total are no richer than they were, they should not alter their consumption in response to the tax cut. It is important to emphasize that the Ricardian argument does not render all fiscal policy irrelevant. If the government cuts taxes today and households expect this tax cut to be met with future cuts in government purchases, then households' permanent income does rise, which stimulates consumption and reduces national saving. But note that it is the expected cut in government purchases, rather than the tax cut, that stimulates consumption. The reduction in expected future government purchases would alter permanent income and consumption because they imply lower taxes at some time, even if current taxes are unchanged.

Because the Ricardian view renders some fiscal policies irrelevant but allows other fiscal policies to matter, providing a convincing test of this view has proven difficult. For example, in the early 1980s, a debt-financed tax cut advocated by President Reagan in his first administration was followed by a substantial rise in government debt and a fall in national saving. Some observers, such as Benjamin Friedman (1992), see this episode as a natural 
experiment that decisively rejects Ricardian equivalence. Yet it is possible that consumers expected this tax cut to mean smaller government in the future; smaller government was, in fact, President Reagan's intention, and to some extent it has been the result. Moreover, other developments, such as a booming stock market, occurred at the same time and surely had some effect on household decisions. In this case, higher consumption and lower national saving could coincide with a tax cut without contradicting Ricardian equivalence. Because neither interpretation of history can be ruled out, both the conventional and Ricardian views of government debt continue to have adherents within the economics profession.

\section{A Brief History of the Ricardian Idea}

The modern literature on Ricardian equivalence began with Robert Barro's 1974 paper. Not only did this paper clearly set out the Ricardian argument but it also anticipated much of the subsequent literature by discussing many of the reasons why Ricardian equivalence might not hold. What the paper did not do, however, was credit Ricardo with the idea. It was not until James Buchanan's 1976 comment on Barro's paper that the term Ricardian equivalence was coined.

Ricardo was interested in the question of how a war might be funded. In an 1820 article, he considered an example of a war that cost 20 million pounds. He noted that if the interest rate were 5 percent, this expense could be financed with a one-time tax of 20 million pounds, a perpetual tax of 1 million pounds, or a tax of 1.2 million pounds for 45 years. He wrote,

"In point of economy, there is no real difference in either of the modes; for twenty millions in one payment, one million per annum for ever, or 1,200,0000 pounds for 45 years, are precisely of the same value..."

Ricardo also was aware that the question raises the issue of intergenerational 
linkages (which we discuss more fully in a later section):

"It would be difficult to convince a man possessed of 20,000 pounds, or any other sum, that a perpetual payment of 50 pounds per annum was equally burdensome with a single tax of 1000 pounds. He would have some vague notion that the 50 pounds per annum would be paid by posterity, and would not be paid by him; but if he leaves his fortune to his son, and leaves it charged with this perpetual tax, where is the difference whether he leaves him 20,000 pounds with the tax, or 19,000 pounds without it?"

Although Ricardo viewed these different methods of government finance as equivalent, he doubted whether other people in fact had in the foresight to act in so rational a manner:

"The people who pay taxes...do not manage their private affairs accordingly. We are apt to think that the war is burdensome only in proportion to what we are at the moment called to pay for it in taxes, without reflecting on the probable duration of such taxes."

And, indeed, Ricardo did not dismiss government debt as an insignificant policy concern. Before the British parliament, he once declared, "This would be the happiest country in the world, and its progress in prosperity would go beyond the powers of imagination to conceive, if we got rid of two great evils--the national debt and the corn laws."19 Because Ricardo doubted the practical validity of Ricardian equivalence, O'Driscoll (1977) suggested the term Ricardian nonequivalence, although this phrase has never caught on. Whether or not Ricardo was a Ricardian, he now gets credit for first noting the possible irrelevance of government debt. More recently, several sources have suggested the possibility of debt

\footnotetext{
${ }^{19}$ Quoted in Buchholz (1989, p. 73). Ricardo's opposition to the corn laws (which restricted the import of grain from abroad) suggests that he took his theory of comparative advantage more seriously than he did his theory of debt neutrality.
} 
neutrality, as Barro in fact noted in his 1974 paper. In 1952, Tobin posed the Ricardian question:

"How is it possible that society merely by the device of incurring a debt to itself can deceive itself into believing that it is wealthier? Do not the additional taxes which are necessary to carry the interest charges reduce the value of other components of private wealth?" Tobin viewed this Ricardian logic as raising an intriguing theoretical question, but he never suggested that it might actually hold in practice. The Ricardian argument also appears in Patinkin's (1965, p. 289) classic treatise, Money, Interest, and Prices, which was based on a 1947 dissertation at the University of Chicago. In considering whether government bonds should be treated as part of household wealth, Patinkin wrote,

"The difficulty with this approach is that the interest burden on these bonds must presumably be financed by future taxes. Hence if the private sector discounts its future tax liabilities in the same way that it discounts future interest receipts, the existence of government bonds will not generate any net wealth effect."

Patinkin does not claim originality for this idea. In a footnote, he says, "This point is due to Carl Christ, who cites in turn discussions with Milton Friedman."

In 1962, Martin Bailey's textbook explained clearly (p. 75) the possibility "that households regard deficit financing as equivalent to taxes." Bailey explains:

"[Government debt] implies future taxes that would not be necessary if the expenditures were financed with current taxation. If a typical household were to save the entire amount that was made available to it by a switch from current taxation to deficit financing, the interest on the saving would meet the future tax charges to pay interest on the government bonds, while the principal saved would be available to meet 
possible future taxes imposed to repay the principal on the government bonds. If the household has a definite idea of how it wants to allocate its total present and future resources among consumption at different points of time, and if it recognizes that the shift from current taxation to deficit financing does not change its total resources at all from a long-run point of view, then it will indeed put entirely into saving any 'income' made available to it by a government decision to finance by bond issue rather than current taxation. That is, the household will consume exactly the same amount, whichever form of financing is used."

Bailey even points out in a footnote that "the same argument applies if no repayment [of the debt's principal] is expected, if the typical household plans to leave an estate." Bailey does not cite Ricardo, but in the text's preface he refers to this section and notes, "a claim to original authorship must be shared with at least two other persons, Gary Becker and Reuben Kessel, who independently developed the same material for their respective courses."

The idea of Ricardian equivalence, therefore, has had a long and distinguished history. Yet there is no doubt that Robert Barro's 1974 paper was a turning point in the literature on government debt. Barro stated the conditions for Ricardian equivalence more clearly than the previous literature had, and he laid out explicitly the intergenerational model needed to establish the result. (We discuss this model below.) Perhaps the greater thoroughness in Barro's treatment of the issue is founded in his apparent belief in debt neutrality. Previous authors, including Ricardo, raised the theoretical possibility of neutrality but often doubted its practical applicability

In a way, Barro can be viewed as the Christopher Columbus of Ricardian equivalence. Columbus was not the first European to discover America, for Leif Ericsson and others had come before. Instead, Columbus's great 
confidence in the importance of his mission ensured that he was the last European to discover America: After Columbus, America stayed discovered. Similarly, Robert Barro was not the first economist to discover Ricardian equivalence, but he was surely the last. Since Barro's work, Ricardian equivalence has maintained its place at the center of the debate over government debt, and no one will be able to discover it again.

\section{Why Ricardian Equivalence is so Important}

Although most economists today agree with David Ricardo and doubt that Ricardian equivalence describes actual consumer behavior, the idea of Ricardian equivalence has been extraordinarily important within the academic debate over government debt. There are two reasons for this.

The first reason is that a small but prominent minority of economists, including Robert Barro, have argued that Ricardian equivalence does in fact describe the world, at least as a first approximation. This small group has provided a useful reminder to the rest of the profession that the conventional view of government debt is far from a scientific certitude. The inability of macroeconomists to perform true experiments makes macroeconomic knowledge open to debate. Although we believe that policymakers are best advised to rely on the conventional view of government debt, we admit that there is room for reasonable disagreement.

The second and more significant reason that Ricardian equivalence is important is that it offers a theoretical benchmark for much further analysis. There are many parallels both inside and outside of economics. Mathematicians study Euclidean geometry (even though we now know that we live in a nonEuclidean world); physicists study frictionless planes (even though all real planes exhibit some friction); and economists study Arrow-Debreu generalequilibrium models with complete and perfectly competitive markets (even though markets in actual economies are neither complete nor perfectly 
competitive)

The theoretical benchmark in economics that is most similar to Ricardian equivalence is the Modigliani-Miller theorem. Modigliani and Miller established conditions under which a firm's choice between debt and equity finance is irrelevant. Similarly, Ricardian equivalence is the claim that the government's choice between debt and tax finance is irrelevant. Few finance economists believe that the Modigliani-Miller theorem describes actual firms' financing decisions. Nonetheless, the theorem provides a starting point for many discussions in corporate finance. Similarly, even if Ricardian equivalence does not describe the world, it can be viewed as one natural starting point in the theoretical analysis of government debt. As the next section should make clear, trying to explain why Ricardian equivalence is not true can yield a deeper understanding about the effects of government debt on the economy.

\section{B. The Debate over Ricardian Equivalence: Theoretical Issues}

Although most economists today are skeptical of the Ricardian proposition that government debt is irrelevant, there is less consensus about why government debt matters. The conventional view (which we discussed earlier) begins with the premise that a debt-financed tax cut stimulates consumption. There are various reasons why this might be the case.

\section{Intergenerational Redistribution}

One reason government debt might matter is that it represents a redistribution of resources across different generations of taxpayers. When the government cuts taxes and issues government debt today, the government budget constraint requires a tax increase in the future, but that tax increase might fall on taxpayers who are not yet living. This redistribution of resources from future to current taxpayers enriches those who are now living; 
current taxpayers respond to the increase in their resources by consuming more. This intergenerational redistribution is the mechanism that makes government debt matter in basic overlapping-generations models, such as those of Diamond (1965) and Blanchard (1985).

Barro's 1974 paper built on Becker's (1974) theory of the family to provide a clever rejoinder to this argument. Barro argued that because future generations are the children and grandchildren of the current generation, it is a mistake to view them as independent economic actors. Instead, Barro suggested that current generations might behave altruistically toward future generations. In the presence of this intergenerational altruism, it is no longer natural to presume that current generations will take advantage of the opportunity to consume at the expense of future generations.

Barro proposed the following model of the family. Suppose that the total utility of generation $t$, denoted $V_{t}$, depends on consumption during its lifetime $C_{t}$ and on the utility of its children $V_{t+1}$, discounted by some factor $\$$ :

$$
V_{t}=U\left(C_{t}\right)+\$ V_{t+1}
$$

Recursive substitution establishes that

$$
V_{t}=U\left(C_{t}\right)+\$ U\left(C_{t+1}\right)+\$ \$^{2} U\left(C_{t+2}\right)+\$ \$^{3} U\left(C_{t+3}\right)+\ldots
$$

That is, the utility of generation $t$ depends on its own consumption and the consumption of all future generations. In essence, the relevant decisionmaking unit is not the individual, who lives only a finite number of years, but the family, which continues forever. As a result, the family member alive today decides how much to consume based not only on his own income but also on the income of future members of his family. Ricardian equivalence is, therefore, preserved: A debt-financed tax cut may raise the income an individual receives in his lifetime, but it does not raise his family's permanent income. Instead of consuming the extra income from the tax cut, the individual saves it and leaves it as a bequest to his descendants, who will 
bear the future tax liability.

The debate over Ricardian equivalence is, therefore, in part a debate over how different generations are linked to one another. This issue has broad significance for macroeconomics. As Kotlikoff and Summers (1981) established, a large fraction of wealth in the U.S. economy is eventually bequeathed rather than consumed by its current owner. ${ }^{20}$ It is possible that many bequests are accidental rather than intentional; that is, people might leave bequests because they die unexpectedly before consuming their entire wealth. Yet the fact that annuity markets (even if imperfect) are used so rarely suggests that consumers must have some desire to leave bequests. The altruism model proposed by Barro is one possible model of the bequest motive, but there are others. Another popular model is the "joy of giving" or "warm glow" model, according to which a person's utility depends on the size of his bequest rather than on the utility of his children. That is, $V_{t}=U\left(C_{t}\right)+G\left(B_{t}\right)$,

where $G\left(B_{t}\right)$ represents the utility from giving a bequest of size $B_{t}$. Closely related to this model is the "strategic bequest motive" proposed by Bernheim, Shleifer, and Summers (1985); according to this model, parents use bequests to induce certain types of behavior from the children, such as visiting home more frequently. These alternative models of the bequest motive do not give individuals any reason to look ahead to their children's tax liabilities and, therefore, do not yield Ricardian equivalence in the presence of policyinduced intergenerational redistributions.

It is sometimes mistakenly claimed that the effects of government debt depend on whether people have finite lives (as is the case in the Diamond overlapping-generations model) or infinite lives (as is effectively the case

\footnotetext{
${ }^{20}$ For other discussions of the role of intergenerational transfers in wealth accumulation, see Gale and Scholz (1994), Kessler and Masson (1989), Kotlikoff (1988), and Modigliani (1988).
} 
in the Barro intergenerational-altruism model). The key issue, however, is not the finiteness of life but the introduction over time of new taxpayers without links to the past. (This point was established by Philippe Weil, 1989.) To see this, imagine an economy in which consumers die (according to some Poisson process) but no new consumers are ever born. In this economy, all future tax liabilities must fall on people who are currently living, so Ricardian equivalence would hold, despite the finiteness of life. By contrast, consider an economy in which new consumers are born over time but, once born, live forever. In this economy, some of the future tax liabilities implied by government debt would fall on future arrivals, and Ricardian equivalence would fail to hold.

The Barro model of intergenerational altruism, which links all future arrivals to those currently living, has attracted a variety of theoretical criticisms. One of the more entertaining is that offered by Bernheim and Bagwell (1988), who build on the well established tenet that human reproduction is sexual and that, as a result, people share common descendants. Indeed, if one looks back and forth among everyone's future family trees, one quickly concludes that the entire world population is connected through a web of familial relationships. This observation, together with intergenerational altruism, yields profound predictions. According to the Barro model, a transfer of a dollar (in present value) between Doug Elmendorf and one of his descendants does not affect anyone's consumption. Similarly, a transfer between Greg Mankiw and one of his descendants does not affect anyone's consumption. But if Elmendorf and Mankiw have common descendants, as surely they must, then a transfer between Elmendorf and Mankiw does not affect anyone's consumption. Indeed, because everyone is connected through common descendants, the entire distribution of income is irrelevant--a prediction that is surely false. Bernheim and Bagwell use this argument as a reductio ad absurdum to conclude that the Barro model cannot describe the relationships 
among generations.

A less intriguing, but ultimately more persuasive, critique of the Barro model of intergenerational altruism arises from the work of Evans (1991), Daniel (1993), and Smetters (1996). Suppose that we consider a standard model of intergenerational altruism but add the seemingly innocuous wrinkle that the degree of altruism (as measured above by the parameter \$) differs across families. Even if all consumers have some degree of altruism, it is likely in the presence of heterogeneity that many consumers will not have operative bequest motives. In the steady state of such a model, the interest rate is determined by the time preference of the most patient family (that is, the family with the highest \$). At this interest rate, other families will choose to hit the corner solution of zero bequests and, therefore, will act like a series of overlapping generations: They will save for life-cycle reasons but will leave no bequests. For these zero-bequest families, transfers of resources across generations will have real effects.

Despite the failure of Ricardian equivalence in this model, the level of government debt does not matter for aggregate variables in the economy's steady state. Because the time preference of the most patient family pins down the steady-state interest rate, it also pins down the capital stock and the level of output. A debt-financed tax cut, for instance, will stimulate consumption, crowd out capital, and raise the real interest rate for a period of time, but the most patient family will respond by increasing saving until, eventually, the capital stock and real interest rate return to their former levels. This result suggests that Ricardian equivalence may work better as a long-run theory than as a short-run theory.

Finally, it is worth noting that, for some purposes, the importance of these intergenerational issues may be overstated. Poterba and Summers (1987) claim that, even without intergenerational altruism, people may have long enough time horizons to make Ricardian equivalence approximately true in the 
short run for some policy interventions. For example, imagine that the government cuts taxes today, issues government debt with an interest rate of 5 percent, and then services the interest payments with higher taxes over the infinite future. In this case, about 77 percent of the future taxes occur within 30 years, indicating that the redistribution of the tax burden toward future generations, though not zero, is relatively small. Moreover, because the marginal propensity to consume out of wealth for life-cycle consumers is relatively small, the redistribution that does occur has only a small effect on consumption. Thus, the immediate result may be an increase in private saving approximately equal to the budget deficit. Poterba and Summers argue that if Ricardian equivalence fails in a substantial way in the short run, the explanation must lie not in the intergenerational redistribution caused by government debt but in some other mechanism. ${ }^{21}$

\section{Capital Market Imperfections}

The simplest, and perhaps most compelling, explanation for the failure of Ricardian equivalence is the existence of capital market imperfections. For households that discount future utility highly or that expect rapidly rising income, the optimal consumption path may require consuming more than their income when young (and less when old) by borrowing in financial markets. The possibility of default and bankruptcy, however, may prevent these households from borrowing for the purposes of current consumption. In this case, the optimal strategy is to consume all of current income and hold exactly zero assets.

\footnotetext{
${ }^{21}$ Even if private saving does rise approximately one-for-one with the budget deficit in the short run, there could be substantial crowding out of capital in the long run. The Auerbach-Kotlikoff simulations discussed earlier suggest that the full effects of government debt take a long time to appear in life-cycle models. Thus, the Poterba-Summers argument raises the possibility-in contrast to the model with heterogeneous altruism just discussed--that Ricardian equivalence may work well as a short-run theory but not as a longrun theory.
} 
In the presence of such a binding borrowing constraint, Ricardian equivalence will no longer hold. A debt-financed tax cut effectively gives the constrained household the loan that it wanted but could not obtain from private lenders. The household will respond by increasing consumption, even with the knowledge that the result is higher taxes and lower consumption in the future.

The potential importance of capital market imperfections is highlighted by the small amount of wealth that many people hold compared to the level of government debt in our economy. In recent years, the federal government debt has been about half of national income. If Ricardian equivalence held, the typical household should be holding additional wealth equal to half of annual income. Yet many households have wealth far below that level. To reconcile Ricardian equivalence with these facts, one would need to believe that in the absence of government debt, most households in the economy would have substantially negative net wealth. This seems implausible: Few consumers are able to obtain substantial loans without tangible collateral. Thus, it seems that government debt has allowed many households to consume more than they otherwise would.

The literature contains some debate over whether capital market imperfections should cause a failure of Ricardian equivalence. Hayashi (1987) and Yotsuzuka (1987) present examples of endogenous capital market imperfections based on asymmetric information that preserve Ricardian equivalence. In these models, asymmetric information about future income, together with the possibility of default, prevents households from borrowing against future income. Yet because taxes are assumed to be lump sum, there is no information problem about the stream of tax payments; as a result, the borrowing constraint does not affect the ability of households to trade off taxes today and taxes in the future. In this case, a debt-financed tax cut causes the borrowing constraint to adjust in such a way as to leave 
consumption opportunities unchanged. As Bernheim (1987) points out, however, this result is crucially dependent on the assumption that taxes are lump sum. If taxes rise with income, then the asymmetry in information about future income causes a similar asymmetry in information about future tax liabilities. In this more realistic case, these models yield the more conventional result that a debt-financed tax cut relaxes the borrowing constraint, allowing households to consume more.

\section{Permanent Postponement of the Tax Burden}

When a person first hears the case for Ricardian equivalence, a natural response is, "Yes, that theory might apply if a budget deficit today required higher taxation in the future. But, in fact, the government never has to pay off its debts. When the government cuts taxes and runs a budget deficit, it can postpone the tax burden indefinitely." This simple argument, it turns out, raises a number of complex questions for economic theory.

The first point to make is that Ricardian equivalence does not require that the government ever pay off its debts in the sense of reaching zero indebtedness. Imagine that the government cuts taxes for one year by dD, increases the government debt by that amount, and then leaves government debt at the new higher level forever. To service this additional government debt would require additional taxes of $r^{*} d D$ every year, where $r$ is the interest rate on the debt. The present discounted value of these higher taxes is dD, which exactly offsets the value of the tax cut. Hence, if consumers look ahead to all future taxes, Ricardian equivalence holds, even though the government never retires the additional debt it has issued.

Matters become more complicated if the government does not raise taxes to finance the interest on this additional debt but, instead, finances these interest payments by issuing even more debt. This policy is sometimes called a "Ponzi scheme" because it resembles investment scams in which old investors 
are paid off with money from new investors. If the government pursues such a Ponzi scheme, the government debt will grow at rate $r$, and the initial tax cut and budget deficit do not imply higher taxes in the future.

But can the government actually get away with this Ponzi scheme? The literature has explored this question extensively. ${ }^{22}$ An important issue is the comparison between the interest rate on government debt $r$ and the growth rate of the economy $g$. If $r$ is greater than $g$, then government debt will increase faster than the economy, and the Ponzi scheme will eventually be rendered infeasible: The debt will grow so large that the government will be unable to find buyers for all of it, forcing either default or a tax increase. By contrast, if $r$ is less than $g$, then government debt will increase more slowly than the economy, and there is nothing to prevent the government from rolling over the debt forever.

The comparison between $r$ and $g$ has broader general-equilibrium implications, however, and these implications help explain the effects of government debt. In standard neoclassical growth theory, $r$ reflects the marginal product of capital, and $g$ reflects population growth and technological change. These two variables can be used to gauge whether the economy has reached a dynamically efficient equilibrium. If $r$ is greater than g, then the economy is efficient in the sense of having less capital than at the "Golden Rule" steady state. By contrast, if $r$ is less than $g$, then the economy in inefficient in the sense of having accumulated too much capital. In this case, a reduction in capital accumulation can potentially increase consumption in all periods of time. A government Ponzi scheme, like the "asset bubbles" studied by Tirole (1985), is both feasible and desirable in such an economy because it helps ameliorate the problem of oversaving.

${ }^{22}$ See, for instance, Ball, Elmendorf, and Mankiw (1995), Blanchard and Weil (1992), Bohn (1993), and O'Connell and Zeldes (1988). 
Dynamic inefficiency and successful, Pareto-improving Ponzi schemes offer an intriguing theoretical possibility, but they are not of great practical relevance for the U.S. economy or other economies around the world. Economists today do not believe that households are saving too much, driving the return to capital below the economy's growth rate. And, indeed, Abel, Mankiw, Summers and Zeckhauser (1989) present evidence for dynamic efficiency. Hence, Ricardian equivalence cannot be refuted by asserting that the government can roll over the debt forever.

Yet one nagging fact remains: In the U.S. economy, the interest rate on government debt has on average been less than the growth rate of the economy. Abel et al. reconcile this fact with their finding of dynamic efficiency by noting that government debt and economic growth have different risk characteristics. They present an example of a dynamically efficient economy in which uncertainty about economic growth drives down the return on risk-free assets, such as government debt, below the average growth rate. Thus, one cannot judge dynamic efficiency (and the feasibility of government Ponzi schemes) simply by comparing the average return on risk-free assets with the average growth rate. ${ }^{23}$

\section{Distortionary Taxes}

The Ricardian equivalence proposition is based on the assumption that taxes are lump sum. If instead taxes are distortionary, then a postponement of the tax burden affects incentives and thereby behavior. These

\footnotetext{
${ }^{23} \mathrm{Ball}$, Elmendorf and Mankiw (1995) build on these ideas and consider policies in dynamically efficient economies called "Ponzi gambles" in which the government cuts taxes and rolls over the resulting debt for as long as is possible. In their model, debt can raise the welfare of all generations in those realizations of history in which taxes do not need to be increased. Yet the policy is a gamble because the government is sometimes forced to raise taxes. Moreover, those tax increases are especially undesirable because they occur in realizations of history in which future generations are already burdened by low economic growth.
} 
microeconomic distortions could have a large macroeconomic impact, making Ricardian equivalence a poor approximation to reality.

To see the potential importance of distortionary taxation, imagine an economy described by the standard Ramsey growth model except that taxes, rather than being lump-sum, are raised with a proportional income tax with rate J. The following equations describe the steady state:

$$
\begin{aligned}
& y=f(k) \\
& J y=r D+g \\
& r=f^{\prime}(k) \\
& (1-\mathrm{J}) r=D
\end{aligned}
$$

The first equation is the production function. The second equation states that tax revenue $J y$ equals the interest on the debt $r D$ plus government spending 9 . The third equation states that the interest rate $r$ equals the marginal product of capital. (Both interest income and capital income are assumed to be taxed at the same rate, so the tax does not affect this equation.) The fourth equation states that the after-tax interest rate equals the rate of subjective time preference D; this is the steady-state condition for the Ramsey model. Given these equations, it is straightforward to see how an increase in government debt affects the economy. Higher debt leads to higher debt service; a higher debt service requires a higher tax rate; a higher tax rate leads to a higher before-tax interest rate; and a higher interest rate leads to a smaller steady-state capital stock. As in the traditional analysis, government debt crowds out capital, even though the mechanism here is quite different.

We can easily calibrate the magnitude of this effect for this model. By fully differentiating this system we obtain an expression to show how much debt crowds out capital:

$$
d k / d D=\left\{J-\left(D f^{\prime \prime} / f^{\prime}\right)+\left[(1-J) f f^{\prime \prime} /\left(f^{\prime}\right)^{2}\right]\right\}^{-1}
$$


If we specialize the production function to Cobb-Douglas $y=k^{\prime \prime}$, then this expression becomes:

$$
d k / d D=\{J+[(1-")(D / k)]-[(1-J)(1-") / "]\}^{-1} \text {. }
$$

For the U.S. economy, taxes take about one-third of income $(\mathrm{J}=1 / 3)$, capital earns about one third of income ("=1/3), and the debt equals about one-seventh of the capital stock $(D / k=1 / 7)$. For these parameter values, $d k / d D=-1.11$. That is, an extra dollar of government debt reduces the steady-state capital stock by slightly over one dollar. This example shows that substantial crowding out can occur simply because of distortionary taxation. ${ }^{24}$

Although this example is sufficient to show the potential importance of distortionary taxation, more realistic analyses of debt policy go beyond this special case. In the steady state of the Ramsey model, national saving is infinitely elastic at the rate of time preference. Other models, such as the life-cycle model of Auerbach and Kotlikoff (1987), would predict a more limited saving response to a change in the after-tax rate of return. In addition, it is important to consider the dynamic effects of tax changes, as in Judd (1987) and Dotsey (1994), and the effects of taxes on labor supply, as in Trostel (1993) and Ludvigson (1996). Perhaps the only certain conclusion is that in a world with distortionary taxation, Ricardian equivalence is unlikely to provide a good first approximation to the true effects of debt policy.

\section{Income Uncertainty}

Another possible reason for the failure of Ricardian equivalence is that government debt may alter consumers' perception of the risks they face. This

\footnotetext{
${ }^{24}$ The numerical results presented here are, of course, sensitive to a variety of detailed assumptions. If we introduce depreciation, so that the production function is $f(k)=k^{\prime \prime}-* k$, then the degree of crowding as measured by $d k / d D$ falls. If we take a broad view of capital, so that " is larger than $1 / 3$, then the degree of crowding rises.
} 
possibility was explored by Chan (1983), Barsky, Mankiw, and Zeldes (1986), Kimball and Mankiw (1989), and Croushore (1996). These authors begin with the axioms that taxes are levied as a function of income and that future income is uncertain. Therefore, when the government cuts taxes today, issues government debt, and raises income taxes in the future to pay off the debt, consumers' expected lifetime income is unchanged, but the uncertainty they face is reduced. If consumers have a precautionary saving motive, this reduction in uncertainty stimulates current consumption. Put differently, consumers discount risky uncertain income and uncertain future taxes at a higher rate than the interest rate on government bonds; a postponement of the tax burden, therefore, encourages current spending.

The potential importance of this mechanism is highlighted by the recent interest in buffer-stock theories of saving. (See, for instance, Carroll, 1997.) In these models, consumers are impatient (in the sense of having a high subjective discount rate) but are nonetheless prudent (in the sense of having a precautionary saving motive). As a result, consumers maintain a small amount of saving in order to protect themselves against unlikely but very adverse shocks to their income. If consumers do not pay significant taxes when these unlikely, adverse outcomes are realized, then a postponement of the tax burden will stimulate current consumption.

\section{Myopia}

When non-economists are explained the idea of Ricardian equivalence, they often have trouble taking the idea seriously. The reason for this response goes to the heart of how economists view human behavior. Rational, optimizing, forward-looking homo economicus is a creature of the economist's imagination. Economists are trained in the power of this model, but noneconomists are often more skeptical. In particular, non-economists are doubtful about whether people have the foresight to look ahead to the future 
taxes implied by government debt, as is required for Ricardian equivalence to hold.

It is hard to incorporate this sort of myopia into economic theory. Yet there have been some attempts to model short-sightedness. Strotz (1956) and Laibson (1997), for instance, consider preferences according to which consumers give excessive weight to current utility (compared to the benchmark case of exponential discounting). As a result, consumers exhibit timeinconsistent behavior and can be made better off through a binding commitment to increased saving. This model can explain the popular notion that people save too little, but it cannot by itself explain a failure of Ricardian equivalence. In this model, the time-inconsistent consumer faces a standard intertemporal budget constraint, so a postponement of the tax burden does not alter the consumer's opportunities. This consumer saves too little but, without a binding borrowing constraint or other imperfection, is fully Ricardian in response to fiscal policy.

Although the Ricardian behavior of Strotz-Laibson consumers shows that myopia by itself need not undermine Ricardian equivalence, this result does not necessarily render myopia irrelevant in this debate. The impatience implicit in the Strotz-Laibson preferences can explain the prevalence of liquidity constraints and buffer-stock saving, which in turn highlights the deviations from Ricardian equivalence emphasized earlier. In addition, it is possible that the Strotz-Laibson approach to modelling myopia is not the best one. Developing better models of myopic behavior remains a challenge for future research.

\section{The Debate over Ricardian Equivalence: Empirical Issues}

The theoretical literature just discussed offers various reasons why government debt may affect consumption and capital accumulation. Yet these deviations from Ricardian equivalence do not prove that the proposition is a 
bad first approximation of the actual economy. To reach such a judgment, one must assess the quantitative importance of these theoretical deviations from the Ricardian benchmark.

Some of the research discussed earlier bears on this issue. As noted above, calculations using the Blanchard model of finite lifetimes imply that debt can crowd out a significant amount of capital, and Auerbach and Kotlikoff's simulations show that the combination of finite lifetimes and distortionary taxes can generate roughly one-for-one crowding out. Moreover, many of the theoretical analyses cited in the previous section include calibrations that illustrate the potential importance of the channels through which debt may affect the economy.

Simulations, however, are no substitute for evidence. In this section we review the empirical evidence on the validity of Ricardian equivalence. We begin with tests of the assumptions underlying the proposition and conclude that a substantial fraction of households probably do not behave as the proposition assumes. We next turn to tests of the proposition's implications for various macroeconomic variables. Despite substantial research in this area, we believe that the results are ultimately inconclusive. ${ }^{25}$

\section{Testing Assumptions About Household Behavior}

When testing theories, economists typically focus on the theories' implications rather than their assumptions. Yet, because testing the implications of Ricardian equivalence raises substantial difficulties, examining the underlying assumptions is also worthwhile. The key assumption is consumption smoothing both within lifetimes and across generations. That is, households are assumed to choose consumption and saving based on a rational evaluation of an intertemporal budget constraint that includes both

${ }^{25}$ Our review of this literature is necessarily brief. For more thorough discussions with additional citations, see Bernheim (1987) and Seater (1993). 
current and future generations.

One piece of evidence that many households do not behave in this way is the small amount of wealth that they hold. This situation may arise from a combination of impatience and borrowing constraints, as described earlier, or because some people are not very forward-looking. In either case, a deficitfinanced tax cut would spur consumption.

Numerous papers also present evidence that people do not smooth consumption fully over time. Campbell and Mankiw (1989) use aggregate data to show that consumption is more sensitive to current income than the basic consumption-smoothing model predicts. Hall and Mishkin (1982), Zeldes (1989), and Carroll and Summers (1991) make the same point using household data. Further confirmation comes from households' responses to changes in taxes and government benefits; for example, see Poterba (1988), Wilcox (1989), and Shapiro and Slemrod (1995). In these studies, deviations from the lifecycle model are economically as well as statistically significant. Some studies, such as Runkle (1991), Attanasio and Browning (1995), and Attanasio and Weber (1995), have argued that income and consumption data are in fact consistent with the consumption-smoothing model. But the weight of the evidence from the consumption literature is that consumption smoothing is far from complete. In our view, this conclusion casts serious doubt on the empirical plausibility of Ricardian equivalence.

\section{Testing the Implications for Consumption}

A large and contentious literature has focused on the implication of Ricardian equivalence that a reduction in current taxes with no change in current or future government spending should not affect household consumption. The standard approach is to estimate a traditional aggregate consumption function, with consumer spending as the dependent variable and income, wealth, fiscal policy, and various other controls as independent variables. Ricardian 
equivalence is rejected if the coefficients on taxes and debt are significantly different from zero.

Although this approach seems to offer a direct test of the Ricardian view, there are a number of problems with its implementation. The first problem is the treatment of expectations. The behavior of forward-looking households depends on expectations of fiscal policy, not just the measures of current fiscal policy that are included in these regressions. Suppose that the current level of taxation reflects expectations of future government spending. (This is in fact implied by the theory of tax-smoothing, which we discuss later.) In this case, a significant negative coefficient on current taxes in the consumption function does not necessarily violate Ricardian equivalence.

A second problem is simultaneity. Some of this literature estimates the consumption function with ordinary least squares. This approach is valid only if the shocks to the consumption function do not affect fiscal policy or other right-hand side variables. Other papers attempt to address this problem using instrumental variables, but finding persuasive instruments is close to impossible. ${ }^{26}$

A third problem in this literature is that the number of observations is small compared with the number of highly correlated explanatory variables. In addition to the basic fiscal variables, some authors include measures of the marginal tax rate, while others separate taxes and spending by the level of government. Still others decompose the income and fiscal variables into permanent and transitory components as a way of capturing expectations. Although there may be good reasons to include these variables as a matter of theory, their addition compounds the problem of multicollinearity. One way to increase the independent variation in the explanatory variables is to use a

\footnotetext{
${ }^{26}$ For a discussion of the identification problem in the context of tests of Ricardian equivalence, see Cardia (1997).
} 
longer estimation period, but this procedure can introduce spans in which consumption is clearly distorted, such as during wars.

A final problem is that these specifications may have little power to distinguish between the Ricardian and conventional views of fiscal policy. As discussed earlier, lifecycle consumers' marginal propensity to consume out of a temporary tax cut may be only a few cents on the dollar. This value may be statistically indistinguishable from the Ricardian benchmark of zero effect. Nonetheless, the difference between a small and a zero marginal propensity to consume is economically important, for a small short-run drop in saving can cumulate to a large long-run decline in the capital stock.

Various recent papers have tried to avoid some of these problems by building on the Euler equation approach pioneered by Hall (1978). By looking at the first-order condition for a representative consumer, rather than an aggregate consumption function, some of the problems in measuring expectations are avoided. Yet the problem of power remains. The first-order condition for a finite-horizon consumer in the Blanchard model is not very different from the first-order condition for an infinite-horizon consumer. Nonetheless, policy can have substantially different effects in the two cases, especially in the long run.

With these problems in mind, it is perhaps not surprising that this literature has failed to reach a consensus on the validity of Ricardian equivalence. Some researchers have concluded that equivalence is a reasonable description of the world; for example, see Kormendi (1983), Aschauer (1985), Seater and Mariano (1985), Evans (1988), and Kormendi and Meguire (1986, 1990, 1995). Other researchers have reached the opposite conclusion; for example, see Feldstein (1982), Modigliani and Sterling (1986, 1990), Feldstein and Elmendorf (1990), Evans (1993), and Graham and Himarios (1991, 1996). Our view is that this literature considered as a whole is simply inconclusive. Many studies that fail to reject Ricardian equivalence are also 
unable to reject the lifecycle model, as their standard errors are large relative to the difference in coefficient values implied by the alternative hypotheses. ${ }^{27}$ Further, some studies that find insignificant effects of taxes on consumption also find insignificant effects of government spending, which is inconsistent with both Ricardian and lifecycle models and suggests that this framework does not reflect the true effects of fiscal policy. ${ }^{28}$ More generally, most results in this literature appear very sensitive to small differences in specification. ${ }^{29}$

\section{Testing the Implications for Interest Rates}

Ricardian equivalence implies that a debt-financed reduction in

government revenue should not affect interest rates. The conventional view of debt generally implies the opposite. An important set of papers tests this implication by examining the effect of the budget deficit on interest rates after controlling for government spending and other influences.

As with the literature concerning the consumption effects of fiscal policy, research into interest-rate effects appears straightforward, but numerous problems quickly arise. Indeed, some of the problems in the two

\footnotetext{
${ }^{27}$ For example, see Evans (1988), Kormendi and Meguire (1990), and Seater and Mariano (1985). The latter paper present an extreme example of lack of power: the authors cannot reject the hypothesis that the coefficient on taxes equals zero, but neither can they reject that it equals minus one.

${ }^{28}$ For example, see Seater and Mariano (1985).

${ }^{29}$ For example, some of the strongest evidence in favor of Ricardian equivalence comes from the especially thorough investigation conducted by Kormendi (1983) and Kormendi and Meguire (1986, 1990, 1995). Yet, Kormendi and Meguire (1990) show that although their results are robust to a variety of changes in specification (table 1), they are not robust to the seemingly innocuous choice of deflator (table 2). For further discussion of Kormendi and Meguire's specification, see the exchanges between them and Barth, Iden, and Russek (1986), Modigliani and Sterling (1986, 1990), and Graham (1995). As another example of the sensitivity of results, Graham and Himarios (1991, 1996) show that the estimates of Aschauer (1985) and Evans (1988) are not robust to alternative formulations of the Euler equation or measures of consumption.
} 
literatures are quite similar.

One problem is that interest rates depend on expectations of fiscal policy and other variables and those expectations are hard to measure. A number of studies use forecasts from vector autoregressions as a proxy for expectations, but the quality of those proxies is unclear. Vector autoregressions assume that variables follow a stable time-series process, and they do not incorporate non-quantitative information. Both of these points are likely to be important, especially for fiscal policy variables, which are the outcome of a political process. Measurement error in the proxies for expectations biases the estimated coefficients toward zero and, thus, toward the null hypothesis of Ricardian equivalence.

A second problem with this approach as a test of Ricardian equivalence is that there is no natural metric for gauging the size of interest-rate effects. For the effect of taxes on consumption, there are natural Keynesian and lifecycle benchmarks as well as the Ricardian benchmark. Indeed, this feature was critical in assessing whether tests of Ricardian equivalence had any power against alternative descriptions of the world. But no such alternative benchmarks exist for interest rates, because the size of the movements expected under non-Ricardian views depends on a host of elasticities. In particular, if international capital flows have an important effect on the domestic financial market, interest rates may not respond much to fiscal policy even if Ricardian equivalence is invalid.

With these caveats in mind, it is worth noting that this literature has typically supported the Ricardian view that budget deficits have no effect on interest rates. Plosser (1982) pioneered the approach of measuring expected policy using vector autoregressions. Further work in this vein by Plosser (1987), Evans (1987a, 1987b), and Boothe and Reid (1989) has confirmed Plosser's original conclusion that a zero effect of deficits cannot be 
rejected. ${ }^{30}$

Our view is that this literature, like the literature regarding the effect of fiscal policy on consumption, is ultimately not very informative. Examined carefully, the results are simply too hard to swallow, for three reasons. First, the estimated effects of policy variables are often not robust to changes in sample period or specification. ${ }^{31}$ Second, the measures of expectations included in the regressions generally explain only a small part of the total variation in interest rates. For example, the average Rsquared of Plosser's basic monthly regressions (1987, tables 6 and 7) is .06, and the corresponding value of Evans's basic quarterly regressions (1987b, table 1) is .09. This poor fit suggests some combination of measurement error in expectations and the omission of other relevant (and possibly correlated) variables. Under either explanation, the estimated coefficients on the policy variables must be viewed with skepticism. Third, Plosser (1987) and Evans (1987b) generally cannot reject the hypothesis that government spending, budget deficits, and monetary policy each have no effect on interest rates. Plosser (1987) also reports that expected inflation has no significant effect on nominal interest rates. These findings suggest that this framework has little power to measure the true effects of policy.

\section{Testing the Implications for International Variables}

Ricardian equivalence implies that a debt-financed reduction in

\footnotetext{
${ }^{30}$ Different sorts of analyses by Evans (1985), Hoelscher (1986), and Wachtel and Young (1987) have reached mixed conclusions.

${ }^{31}$ For example, Plosser (1987, table 10) reports sharply different coefficient estimates during the 1968-76 and 1977-85 sample periods and using monthly data as opposed to quarterly data. As another example, Evans (1987a, tables 1 and 2) estimates that budget deficits had a small and statistically insignificant effect on nominal interest rates during the 1950s, 1960s and 1970s, but an effect that was large, statistically significant, and surprisingly negative between 1979 and 1984. Of course, the effect of budget deficits may well have changed over time, but an estimated shift of this magnitude signals some problem with specification.
} 
government revenue should not affect the exchange rate or the current account. In contrast, the conventional view of debt implies that the exchange rate should appreciate in these circumstances and the trade deficit should increase. Several researchers have tested these implications and reached conflicting conclusions.

Evans (1986) applies to exchange rates the methodology used by Plosser and Evans to study the effect of budget deficits on interest rates. He concludes that U.S. budget deficits tend to cause a depreciation of the dollar, in contrast to both the Ricardian and conventional views. Evans's analysis is subject to the same problems that plague the interest-rate literature discussed above. ${ }^{32}$ Moreover, a decline in the dollar should cause a strengthening of the trade balance. Yet Bernheim (1988) and Rosensweig and Tallman (1993) conclude that U.S. trade deficits worsen when the U.S. budget deficit increases.

In the end, the empirical literature examining the effects of fiscal policy on consumption, interest rates, and international variables fails to offer clear evidence either for or against the Ricardian hypothesis. If the evidence is so weak, why then do most economists feel confident in rejecting Ricardian equivalence as a description of the world? The answer, we believe, is that most economists are incredulous about the assumptions that are needed to support the Ricardian view of government debt. In this case, the debate over theory is more persuasive than the debate over evidence.

\section{Optimal Debt Policy}

Disagreement about the appropriate amount of government debt in the United States is as old as the country itself. Alexander Hamilton (1781) believed that "a national debt, if it is not excessive, will be to us a

${ }^{32}$ For example, fewer than half of the estimated coefficients reported by Evans (1986, tables 1 and 7) are statistically distinguishable from zero. 
national blessing," while James Madison (1790) argued that "a public debt is a public curse." Indeed, the location of the nation's capital was chosen as part of a deal in which the federal government assumed the Revolutionary War debts of the states: Because the Northern states had larger outstanding debts, the capital was located in the South. Attention to the national debt has waxed and waned over the years, but has been intense during the past two decades. Similarly, government debt and deficits have been a focus of recent public debate in many European countries.

The appropriate use of government debt depends on how debt affects the economy. As we have seen in the theoretical debate over Ricardian equivalence, debt could potentially have many different effects. As a result, the literature on optimal debt policy is broad in scope. Here we focus on the three effects that are most often viewed as important: the use of debt policy to reduce the magnitude of economic fluctuations, the use of debt policy to increase national saving, and the use of debt policy to reduce tax distortions by smoothing taxes over time.

\title{
A. Fiscal Policy over the Business Cycle
}

\author{
Although some economists argue that fluctuations in aggregate output \\ represent an optimal response to shifts in preferences or technology, most \\ economists believe that some output variability arises from rigidities or \\ coordination failures. These changes in output, and especially shortfalls of \\ output relative to the potential determined by the available factors of \\ production, are socially costly. In this case, timely adjustments to the \\ government deficit and debt may raise social welfare. This notion of \\ "countercyclical fiscal policy" dates at least to Keynes, and Blinder and \\ Solow (1973) present one of the classic analyses. \\ Countercyclical fiscal policy arises automatically from the design of \\ tax and transfer programs. When output and income are high, tax liabilities
}


rise and eligibility for government benefits falls, reducing the budget deficit; when output and income are low, these effects reverse and the deficit widens. These "automatic stabilizers" are important quantitatively. CBO (1997a) estimates that when real output falls by 1 percent, tax revenue declines by about 1 percent.

Countercyclical fiscal policy may also be implemented on a discretionary basis. For example, during the 1975 recession, Gerald Ford and Congress agreed to a small cut in personal income taxes. Over time, however, this sort of policy has fallen into disfavor. During the 1990 recession, for instance, taxpayers received a reduction in tax withholding but not their tax liability. Part of this shift in views comes from a realization that an explicitly temporary change in taxes has only a small effect on the consumption of forward-looking consumers. Moreover, there are generally long lags in enacting discretionary changes in fiscal policy, so any effect on aggregate demand may be poorly timed. Finally, and perhaps most important, there is an increased appreciation for the ability of the Federal Reserve to conduct effective countercyclical monetary policy.

\section{B. Fiscal Policy and National Saving}

The most important long-run effect of government debt under the conventional view is to reduce national wealth. Thus, optimal debt policy in the long run depends primarily on optimal national saving. Current public debate often takes as given the notion that saving should be increased. Proving this point, however, is by no means straightforward. Bernheim (1994), Lazear (1994) and Hubbard and Skinner (1996) provide recent discussions of why more saving might be desirable. Examining this topic in detail is beyond the scope of this paper, but we consider briefly the issues that relate to government debt. We consider first whether debt policy should be used to make

people save more for their own retirement, and then whether debt policy should 
be used to make current generations leave more wealth to future ones.

\section{Life-Cycle Saving}

Feldstein (1985) argues that people should do more saving within their lifetimes because the marginal product of capital exceeds their marginal rate of substitution between present and future consumption. This wedge arises, he argues, because of the taxation of capital income. He is surely right that capital taxation distorts households' consumption decisions. But does this imply that debt policy should be used to increase national saving? The answer is not obvious.

Suppose that people are life-cycle consumers whose consumption is distorted by capital taxation. Eliminating the distortion would be desirable, but this goal cannot be achieved simply through debt policy. For instance, if the government raises lump-sum taxation today, reduces government debt, and thereby reduces lump-sum taxation later within these consumers' lifetimes, Ricardian equivalence obtains, and national saving does not change. By contrast, Ricardian equivalence fails to hold if the future tax reductions benefit future generations. In this case, national saving rises because the income effect of current taxation reduces current generations' consumption. Nonetheless, the distortion between current and future consumption of any given generation is unchanged. That is, the increase in national saving induced by debt policy does not mitigate the distortionary effects of capital taxation.

When considering how policy affects national saving, it is important to distinguish between the allocation of consumption across a person's lifetime and the allocation of consumption across generations. Capital taxation inefficiently encourages consumption when a person is young compared to consumption when the same person is old. In a life-cycle model, however, debt policy does not affect this comparison. Instead, debt policy affects the 
consumption of current generations compared to the consumption of future generations. Thus, in a life-cycle model with rational consumers and distortionary capital taxes, life-cycle saving is inefficiently low, but debt policy cannot remedy the problem.

\section{Intergenerational Saving}

Debt policy can affect national saving by transferring resources among generations of life-cycle consumers. One approach to intergenerational equity in the context of debt policy is to focus on the appropriate distribution of paying for government services. The "benefit principle" implies that current spending should be financed out of current taxes, but capital spending should be financed over the life of the capital. Musgrave (1959) advocated this approach, terming it "pay-as-you-use finance" (p. 558).33 This principle provides one justification for the practice of financing wars--which are expected to benefit future as well as current generations--largely through debt issuance.

Another approach to intergenerational concerns about government debt is to consider the overall welfare of different generations using an explicit social welfare function. As Romer (1988) notes, a utilitarian social planner discounts income at the rate $*=2+g / F$, where 2 is the intergenerational discount rate for utility, $g$ is the growth rate of income, and $F$ is the intertemporal elasticity of substitution (which equals the inverse of the elasticity of marginal utility with respect to consumption). Income growth matters here because it reduces the utility gained from an extra dollar of income. If the net marginal product of capital $r$ exceeds $*$, then deferring consumption to future generations is socially optimal.

Applying this criterion is by no means straightforward. Obviously, one

${ }^{33}$ Musgrave also argued that the budget deficit should vary over the business cycle for stabilization purposes. 
must determine how much to discount the utility of future generations. One might argue that zero is the most consistent with people choosing a social welfare function "behind a veil of ignorance" (Rawls, 1971) about the generation to which they belong. If $2=0,9=.01$, and $F=.33$, the social discount rate $*$ is 0.03 . If $r=.06$, which is the value we used earlier, the net gain from deferring consumption (r-*) is .03. One is thus led to conclude that increased national saving would be desirable. Yet the opposite conclusion arises if $\mathrm{F}=.1$, so that * is 0.1 . In this case, economic growth together with sharply diminishing marginal utility ensures that the marginal utility of future generations is low, so there is little benefit to saving on their behalf. In the end, therefore, the utilitarian approach to intergenerational saving illuminates the key parameters that determine optimal national saving, but it does not allow us to reach an easy conclusion on whether national saving is in fact too low or too high.

\section{Tax Smoothing}

Another approach to analyzing optimal debt policy, advocated by Barro (1979), emphasizes the distortionary nature of taxation. The deadweight loss from a tax depends roughly on the square of the tax rate. Thus, the distortion-minimizing way to finance a given stream of government spending is to maintain a smooth tax rate over time. If future government spending were known with certainty, the optimal tax rate would be constant. Because future government spending is uncertain, the optimal tax rate sets the present value of revenue equal to the present value of expected spending. As information about spending becomes available, the optimal tax rate changes. Under this view, the budget deficit is simply the difference between government spending and the amount of revenue generated by this tax rate, and the debt will rise and fall accordingly over time.

\footnotetext{
Barro's tax-smoothing model is formally parallel to Friedman's
} 
permanent-income hypothesis. According to the permanent-income hypothesis, households smooth consumption by basing it on their expected permanent income; they save and borrow in response to transitory changes in income. According to the tax-smoothing model, governments smooth tax rates by basing tax rates on expected permanent government spending; they increase or decrease government debt in response to transitory changes in spending or revenue. Barro (1979) finds that the tax-smoothing theory of debt explains fairly well the behavior of U.S. debt since 1920, and Barro (1987) reaches a similar conclusion for British debt from 1700 through World War I. Much of the variation in spending that Barro studies is related to wars. Thus, the taxsmoothing logic provides another justification (in addition to intergenerational equity) for accumulating government debt during wars and paying off the debt during peacetime.

\section{v. Conclusion}

This essay has touched on some of the major issues in the debates over the effects of government debt. Because of the broad scope of this topic, we have had to be selective. We have ignored many important related subjects, such as the management of government debt with instruments of varying maturities, the debate over inflation-indexed debt, the pros and cons of alternative rules for setting fiscal policy, and the theories of political economy that attempt to explain why and when governments issue debt. We trust that readers who have made it to this conclusion will understand why we avoided these additional fascinating but extensive topics. 


\section{References}

Abel, Andrew B., N. Gregory Mankiw, Lawrence H. Summers, and Richard J. Zeckhauser, "Assessing Dynamic Efficiency: Theory and Evidence," Review of Economic Studies 56 (January 1989): 1-20.

Aiyagari, S. Rao and Mark Gertler, "The Backing of Government Bonds and Monetarism," Journal of Monetary Economics 16 (July 1985): 19-44.

Aschauer, David Alan, "Fiscal Policy and Aggregate Demand," American Economic Review 75 (March 1985): 117-127.

Attanasio, Orazio P. and Martin Browning, "Consumption over the Life Cycle and over the Business Cycle," American Economic Review 85 (December 1995): 1118-1137.

Attanasio, Orazio P. and Guglielmo Weber, "Is Consumption Growth Consistent with Intertemporal Optimization? Evidence from the Consumer Expenditure Survey," Journal of Political Economy 103 (December 1995): 1121-1157.

Auerbach, Alan J., and Laurence J. Kotlikoff, Dynamic Fiscal Policy, Cambridge: Cambridge University Press (1987).

Auerbach, Alan J., Jagadeesh Gokhale, and Laurence J. Kotlikoff, "Generational Accounts: A Meaningful Alternative to Deficit Accounting," Tax Policy and the Economy 5 (1991): 55-110.

Bailey, Martin J., National Income and the Price Level, New York: McGraw-Hill (1962).

Ball, Laurence, Douglas W. Elmendorf, and N. Gregory Mankiw, "The Deficit Gamble," National Bureau of Economic Research Working Paper No. 5015 (February 1995), forthcoming in the Journal of Money, Credit, and Banking.

Ball, Laurence, and N. Gregory Mankiw, "What Do Budget Deficits Do?," Budget Deficits and Debt: Issues and Options, Federal Reserve Bank of Kansas City (1995): 95-119.

Ballard, Charles, John Shoven, and John Whalley, "General Equilibrium Computations of the Marginal Welfare Cost of Taxes in the United States," American Economic Review 75 (March 1985): 128-138.

Barro, Robert J., "Are Government Bonds Net Wealth?," Journal of Political Economy 82 (November/December 1974): 1095-1117.

Barro, Robert J., "On the Determination of the Public Debt," Journal of Political Economy 87 (October 1979): 940-971.

Barro, Robert J., "Government Spending, Interest Rates, Prices, and Budget Deficits in the United Kingdom, 1701-1918," Journal of Monetary Economics 20 (September 1987) : 221-247.

Barro, Robert J., N. Gregory Mankiw, and Xavier Sala-i-Martin, "Capital 
Mobility in Neoclassical Models of Growth," American Economic Review 85 (March 1995): 103-115.

Barsky, Robert B., N. Gregory Mankiw, and Stephen P. Zeldes, "Ricardian Consumers with Keynesian Propensities," American Economic Review 76 (September 1986): 676-691.

Barth, James R., George Iden, and Frank S. Russek, "Government Debt, Government Spending, and Private Sector Behavior: Comment," American Economic Review 76 (December 1986): 1158-1167.

Becker, Gary S., "A Theory of Social Interactions," Journal of Political Economy 82 (November/December 1974): 1063-1093.

Bernheim, B. Douglas, "Ricardian Equivalence: An Evaluation of Theory and Evidence," NBER Macroeconomics Annual (1987): 263-303.

Bernheim, B. Douglas, "Budget Deficits and the Balance of Trade," Tax Policy and the Economy (1988): 1-31.

Bernheim, B. Douglas, "Comment," in Studies in the Economics of Aging, David A. Wise, ed., Chicago: University of Chicago Press (1994): 171-179.

Bernheim, B. Douglas, and Kyle Bagwell, "Is Everything Neutral?," Journal of Political Economy 96 (April 1988): 308-338.

Bernheim, B. Douglas, Andrei Shleifer, and Lawrence H. Summers, "The Strategic Bequest Motive," Journal of Political Economy 93 (December 1985): 10451076 .

Berry, Thomas Senior, "Revised Annual Estimates of American Gross National Product," Bostwick Paper No. 3, The Bostwick Press (1978).

Blanchard, Olivier J., "Debt, Deficits, and Finite Horizons," Journal of Political Economy 93 (April 1985): 223-247.

Blanchard, Olivier J., and Stanley Fischer, Lectures on Macroeconomics, Cambridge, MA: The MIT Press (1989).

Blanchard, Olivier J. and Lawrence H. Summers, "Perspectives on High World Real Interest Rates," Brookings Papers on Economic Activity (1984:2): 273-334.

Blanchard, Olivier J. and Phillipe Weil, "Dynamic Efficiency, the Riskless Rate, and Debt Ponzi Games under Uncertainty," NBER Working Paper \#3992, February 1992 .

Blinder, Alan S., and Robert M. Solow, "Does Fiscal Policy Matter?," Journal of Public Economics 2 (November 1973): 319-337.

Bohn, Henning, "Budget Deficits and Government Accounting," Carnegie-Rochester Conference Series on Public Policy 37 (December 1992): 1-84.

Bohn, Henning, "Fiscal Policy and the Mehra-Prescott Puzzle: On the Welfare Implications of Budget Deficits When Real Interest Rates are Low," Department of Economics, University of California at Santa Barbera, 
Working Paper No. 8-93, 1993.

Boothe, Paul M. and Bradford G. Reid, "Asset Returns and Government Budgets in a Small Open Economy," Journal of Monetary Economics, 23 (January 1989): 65-77.

Buchanan, James M., "Barro on the Ricardian Equivalence Theorem, "Journal of Political Economy 84 (April 1976): 337-342.

Buchanan, James M., and Richard E. Wagner, Democracy in Deficit: The Political Economy of Lord Keynes, New York: Academic Press (1977).

Buchholz, Todd G., New Ideas from Dead Economists: An Introduction to Modern Economic Thought, New York: Penguin (1989).

Bureau of the Census, Historical Statistics of the United States, Colonial Times to 1970, Part 2, Washington, D.C. (1975).

Butkiewicz, James L., "The Market Value of Outstanding Government Debt: Comment," Journal of Monetary Economics 11 (May 1983): 373-379.

Campbell, John Y. and N. Gregory Mankiw, "Consumption, Income and Interest Rates: Reinterpreting the Time Series Evidence," NBER Macroeconomics Annual (1989): 185-216.

Cardia, Emanuela, "Replicating Ricardian Equivalence Tests with Simulated Series," American Economic Review 87 (March 1997): 65-79.

Carroll, Christopher D., "Buffer-Stock Saving and the Life Cycle/Permanent Income Hypothesis," Quarterly Journal of Economics 112 (February 1997): $1-55$.

Carroll, Christopher D. and Lawrence H. Summers, "Consumption Growth Parallels Income Growth: Some New Evidence," in National Saving and Economic Performance, B. Douglas Bernheim and John B. Shoven, eds., Chicago: University of Chicago Press (1991): 305-343.

"Caught in the Debt Trap," The Economist, April 1, 1995.

Chan, Louis K.C., "Uncertainty and the Neutrality of Government Financing Policy," Journal of Monetary Economics 11 (May 1983): 351-372.

Congressional Budget Office, Federal Debt and Interest Costs, Washington, D.C. (May 1993).

Congressional Budget Office, Who Pays and When? An Assessment of Generational Accounting, Washington, D.C. (November 1995).

Congressional Budget Office, The Economic and Budget Outlook: Fiscal Years 1998-2007, Washington, D.C. (January 1997a).

Congressional Budget Office, Long-Term Budgetary Pressures and Policy Options, Washington, D.C. (March 1997b).

Cox, W. Michael and Eric Hirschhorn, "The Market Value of Outstanding Government Debt: Monthly, 1942-1980," Journal of Monetary Economics 11 
(March 1983): 261-272.

Council of Economic Advisers, Economic Report of the President, Washington, D.C. (February 1994).

Croushore, Dean, "Ricardian Equivalence with Wage-Rate Uncertainty," Journal of Money, Credit, and Banking 28 (August 1996): 279-293.

Cutler, David M., "Book Review of Laurence Kotlikoff's Generational Accounting," National Tax Journal, 56 (March 1993): 61-67.

Daniel, Betty C, "Tax Timing and Liquidity Constraints: A Heterogeneous-Agent Model," Journal of Money, Credit, and Banking 25 (May 1993): 176-196.

Diamond, Peter A., "National Debt in a Neoclassical Growth Model," American Economic Review 55 (December 1965): 1126-1150.

Dornbusch, Rudiger, "Comment on Feldstein and Bacchetta," in National Saving and Economic Performance, B. Douglas Bernheim and John B. Shoven, eds., Chicago: University of Chicago Press (1991): 220-226.

Dotsey, Michael, "Some Unpleasant Supply Side Arithmetic," Journal of Monetary Economics 33 (1994): 507-524.

Eisner, Robert, How Real is the Federal Deficit?, New York: The Free Press $(1986)$.

Eisner, Robert, and Paul J. Pieper, "A New View of the Federal Debt and Budget Deficits," American Economic Review 74 (March 1984): 11-29.

Evans, Paul, "Do Large Deficits Produce High Interest Rates?," American Economic Review 75 (March 1985): 68-87.

Evans, Paul, "Is the Dollar High Because of Large Budget Deficits?," Journal of Monetary Economics 18 (November 1986) : 227-249.

Evans, Paul, "Interest Rates and Expected Future Budget Deficits in the United States," Journal of Political Economy 95 (February 1987a): 34-58.

Evans, Paul, "Do Budget Deficits Raise Nominal Interest Rates? Evidence from Six Countries," Journal of Monetary Economics 20 (September 1987b) : 281300 .

Evans, Paul, "Are Consumers Ricardian? Evidence for the United States," Journal of Political Economy 96 (October 1988): 983-1004.

Evans, Paul, "Is Ricardian Equivalence a Good Approximation?," Economic Inquiry 29 (October 1991): 626-644.

Evans, Paul, "Consumers Are Not Ricardian: Evidence from Nineteen Countries," Economic Inquiry 31 (October 1993) : 534-548.

Feldstein, Martin, "Government Deficits and Aggregate Demand," Journal of Monetary Economics 9 (January 1982): 1-20.

Feldstein, Martin, "Debt and Taxes in the Theory of Public Finance," Journal 
of Public Economics 28 (November 1985): 233-245.

Feldstein, Martin, "Overview Panelist," Budget Deficits and Debt: Issues and Options, Federal Reserve Bank of Kansas City (1995): 403-412.

Feldstein, Martin, "The Missing Piece in Policy Analysis: Social Security Reform," American Economic Review 86 (May 1996a): 1-14.

Feldstein, Martin, "How Big Should Government Be?," National Tax Association Proceedings (1996b): 314-326.

Feldstein, Martin and Philippe Bacchetta, "National Saving and International Investment," in National Saving and Economic Performance, B. Douglas Bernheim and John B. Shoven, eds., Chicago: University of Chicago Press (1991): 201-220.

Feldstein, Martin, Louis Dicks-Mireaux, and James M. Poterba, "The Effective Tax Rate and the Pretax Rate of Return," Journal of Public Economics 21 (July 1983): 129-158.

Feldstein, Martin and Douglas W. Elmendorf, "Government Debt, Government Spending, and Private Sector Behavior Revisited: Comment," American Economic Review 80 (June 1990): 589-599.

Feldstein, Martin and Charles Horioka, "Domestic Saving and International Capital Flows," Economic Journal 90 (June 1980): 314-29.

Frankel, Jeffrey A., "Quantifying International Capital Mobility in the 1980s," in National Saving and Economic Performance, B. Douglas Bernheim and John B. Shoven, eds., Chicago: University of Chicago Press (1991): 227-260.

Frenkel, Jacob A. and Assaf Razin, Fiscal Policies and the World Economy, Cambridge, Massachusetts: MIT Press (1992).

Friedman, Benjamin M., Day of Reckoning, New York: Random House (1988).

Friedman, Benjamin M., "Learning from the Reagan Deficits," American Economic Review 82 (May 1992): 299-304.

Gale, William G. and John Karl Scholz, "Intergenerational Transfers and the Accumulation of Wealth," Journal of Economic Perspectives 8 (Fall 1994): 145-160.

Gordon, Roger H. and A. Lans Bovenberg, "Why Is Capital So Immobile Internationally? Possible Explanations and Implications for Capital Income Taxation," American Economic Review 86 (December 1996): 10571075 .

Graham, Fred C., "Government Debt, Government Spending, and Private-Sector Behavior: Comment," American Economic Review 85 (December 1995): 13481356 .

Graham, Fred C. and Daniel Himarios, "Fiscal Policy and Private Consumption: Instrumental Variables Tests of the 'Consolidated Approach'," Journal of Money, Credit, and Banking 23 (February 1991): 53-67. 
Graham, Fred C. and Daniel Himarios, "Consumption, Wealth, and Finite Horizons: Tests of Ricardian Equivalence," Economic Inquiry 34 (July 1996) : 527-544.

Greenspan, Alan, "General Discussion," Budget Deficits and Debt: Issues and Options, Federal Reserve Bank of Kansas City (1995): 139-149.

Hall, Robert E. "Stochastic Implications of the Life Cycle-Permanent Income Hypothesis: Theory and Evidence," Journal of Political Economy 86 (December 1978): 971-987.

Hall, Robert E. and Frederic S. Mishkin, "The Sensitivity of Consumption to Transitory Income: Estimates from Panel Data on Households," Econometrica 50 (March 1982): 461-481.

Hamilton, Alexander, "Letter to Robert Morris," April 30, 1781.

Hayashi, Fumio, "Tests for Liquidity Constraints: A Critical Survey," Advances in Econometrics: Fifth World Congress, ed. Truman Bewley, New York, Cambridge University Press (1987).

Hoelscher, Gregory, "New Evidence on Deficits and Interest Rates," Journal of Money, Credit, and Banking 18 (February 1986): 1-17.

Hubbard, R. Glenn, and Jonathan S. Skinner, "Assessing the Effectiveness of Saving Incentives," Journal of Economic Perspectives 10 (Fall 1996): 7390 .

Judd, Kenneth, "Debt and Distortionary Taxation in a Simple Perfect Foresight Model," Journal of Monetary Economics 20 (1987): 51-72.

Kessler, Denis and Andre Masson, "Bequest and Wealth Accumulation: Are Some Pieces of the Puzzle Missing?" Journal of Economic Perspectives 3 (Summer 1989): 141-152.

Kimball, Miles S. and N. Gregory Mankiw, "Precautionary Saving and the Timing of Taxes," Journal of Political Economy 97 (August 1989): 863-879.

Kormendi, Roger C., "Government Debt, Government Spending, and Private Sector Behavior," American Economic Review 73 (December 1983): 994-1010.

Kormendi, Roger C. and Philip Meguire, "Government Debt, Government Spending, and Private Sector Behavior: Reply," American Economic Review 76 (December 1986): 1180-1187.

Kormendi, Roger C. and Philip Meguire, "Government Debt, Government Spending, and Private Sector Behavior: Reply and Update," American Economic Review 80 (June 1990): 604-617.

Kormendi, Roger C. and Philip Meguire, "Government Debt, Government Spending, and Private Sector Behavior: Reply," American Economic Review 85 (December 1995): 1357-1361.

Kotlikoff, Laurence J., "Intergenerational Transfers and Savings," Journal of Economic Perspectives 2 (Spring 1988): 41-58. 
Kotlikoff, Laurence J., Generational Accounting: Knowing Who Pays, and When, for What We Spend, New York: The Free Press (1992).

Kotlikoff, Laurence J. and Lawrence H. Summers, "The Role of Intergenerational Transfers in Aggregate Capital Accumulation," Journal of Political Economy 89 (August 1981): 706-732.

Krugman, Paul, "International Aspects of Financial Crises," in The Risk of Economic Crisis, Martin Feldstein, ed., Chicago: University of Chicago Press, 1991.

Laibson, David, "Golden Eggs and Hyperbolic Discounting," Quarterly Journal of Economics (May 1997): 443-477.

Lazear, Edward P., "Some Thoughts on Savings," in Studies in the Economics of Aging, David A. Wise, ed., Chicago: University of Chicago Press (1994): 143-169.

Leeper, Eric, "Equilibria under 'Active' and 'Passive' Monetary Policies, Journal of Monetary Economics 27 (February 1991): 129-147.

Ludvigson, Sydney, "The Macroeconomic Effects of Government Debt in a Stochastic Growth Model," Journal of Monetary Economics 38 (1996): 2545.

Madison, James, "Letter to Henry Lee," April 13, 1790.

Mankiw, N. Gregory, "The Growth of Nations," Brookings Papers on Economic Activity (1995:1): 275-326.

Mankiw, N. Gregory, David Romer, and David N. Weil, "A Contribution to the Empirics of Economic Growth," Quarterly Journal of Economics 107 (May $1992)$ : 407-437.

Marris, Stephen, Deficits and the Dollar: The World Economy at Risk, Washington, D.C.: Institute for International Economics (1985).

McCallum, Bennett T., "Are Bond-Financed Deficits Inflationary? A Ricardian Analysis," Journal of Political Economy 92 (February 1984): 123-135.

Modigliani, Franco, "The Role of Intergenerational Transfers and Life Cycle Saving in the Accumulation of Wealth," Journal of Economic Perspectives 2 (Spring 1988), 15-40.

Modigliani, Franco and Arlie Sterling, "Government Debt, Government Spending, and Private Sector Behavior: Comment," American Economic Review 76 (December 1986): 1168-1179.

Modigliani, Franco and Arlie Sterling, "Government Debt, Government Spending, and Private Sector Behavior: A Further Comment," American Economic Review 80 (June 1990): 600-603.

Musgrave, Richard A., The Theory of Public Finance, New York: McGraw-Hill (1959).

Mussa, Michael and Morris Goldstein, "The Integration of World Capital 
Markets," Changing Capital Markets: Implications for Monetary Policy, Federal Reserve Bank of Kansas City (1993): 245-313.

Obstfeld, Maurice and Kenneth Rogoff, Foundations of International Macroeconomics, Cambridge, Massachusetts: MIT Press (1996).

O'Connell, Stephen A. and Stephen P. Zeldes, "Rational Ponzi Games," International Economic Review 29 (August 1988): 431-450.

O'Driscoll, Gerald P., "The Ricardian Nonequivalence Theorem," Journal of Political Economy 85 (February 1977): 207-210.

Office of Management and Budget, Analytical Perspectives, Budget of the United States Government, Fiscal Year 1997, Washington, D.C. (1996).

Organization of Economic Cooperation and Development, Economic Outlook, Paris (June 1997).

Patinkin, Don, Money, Interest and Prices, New York: Harper and Row (1965) .

Plosser, Charles I., "Government Financing Decisions and Asset Returns," Journal of Monetary Economics 9 (May 1982) : 325-352.

Plosser, Charles I., "Fiscal Policy and the Term Structure," Journal of Monetary Economics 20 (September 1987): 343-367.

Poterba, James M., "Are Consumers Forward-Looking? Evidence from Fiscal Experiments," American Economic Review 78 (May 1988): 413-418.

Poterba, James M., and Lawrence H. Summers, "Finite Lifetimes and the Effects of Budget Deficits on National Saving," Journal of Monetary Economics 20 (1987): 369-391.

Rawls, John, A Theory of Justice, Cambridge, Mass.: Harvard University Press (1971).

Ricardo, David, "Funding System," 1820, reprinted in The Works and Correspondence of David Ricardo, edited by P. Sraffa, Cambridge: Cambridge University Press, 1951.

Romer, Christina D., "The Prewar Business Cycle Reconsidered: New Estimates of Gross National Product, 1869-1928," Journal of Political Economy 97 (February 1989): 1-37.

Romer, David, "What Are the Costs of Excessive Deficits?," NBER Macroeconomics Annual (1988): 63-98.

Romer, Paul M., "Increasing Returns and Long-Run Growth," Journal of Political Economy 94 (October 1986): 1002-1037.

Romer, Paul M., "Crazy Explanations for the Productivity Slowdown," NBER Macroeconomics Annual (1987): 163-202.

Rosensweig, Jeffrey A. and Ellis W. Tallman, "Fiscal Policy and Trade Adjustment: Are the Deficits Really Twins?," Economic Inquiry 31 (October 1993): 580-594. 
Roseveare, Deborah, Willi Leibfritz, Douglas Fore, and Eckhard Wurzel, "Ageing Populations, Pension Systems and Government Budgets: Simulations for 20 OECD Countries," OECD Economics Department Working Paper No. 168 (1996).

Runkle, David E., "Liquidity Constraints and the Permanent-Income Hypothesis: Evidence from Panel Data," Journal of Monetary Economics 27 (February 1991): $73-98$.

Samuelson, Paul A., "An Exact Consumption Loan Model of Interest With or Without the Social Contrivance of Money," Journal of Political Economy 66 (December 1958): 467-482.

Sargent, Thomas J., "The Ends of Four Big Inflations," in Inflation, Robert E. Hall, ed., Chicago: University of Chicago Press (1983): 41-93.

Sargent, Thomas J. and Neil Wallace, "Some Unpleasant Monetarist Arithmetic," Quarterly Review, Federal Reserve Bank of Minneapolis (Fall 1981).

Seater, John J., "The Market Value of Outstanding Government Debt, 1919-1975," Journal of Monetary Economics 8 (July 1981): 85-101.

Seater, John J., "Ricardian Equivalence," Journal of Economic Literature 31 (March 1993): 142-190.

Seater, John J. and Roberto S. Mariano, "New Tests of the Life Cycle and Tax Discounting Hypotheses," Journal of Monetary Economics 15 (March 1985): 195-215.

Shapiro, Matthew D. and Joel Slemrod, "Consumer Response to the Timing of Income: Evidence from a Change in Tax Withholding," American Economic Review 85 (March 1995) : 274-283.

Sims, Christopher A., "A Simple Model for the Determination of the Price Level and the Interaction of Monetary and Fiscal Policy," Economic Theory 4 (3: 1994): 381-399.

Smetters, Kent A., "Ricardian Equivalence: Long-Run Leviathan," Congressional Budget Office, mimeo (1996).

Solow, Robert M., "A Contribution to the Theory of Economic Growth," Quarterly Journal of Economics 70 (February 1956): 65-94.

Stocks, Bonds, Bills and Inflation 1995 Yearbook, Chicago: Ibbotson Associates (1995).

Strotz, Robert H., "Myopia and Inconsistency in Dynamic Utility Maximization," Review of Economic Studies 23 (1956): 165-180.

Tirole, Jean, "Asset Bubbles and Overlapping Generations," Econometrica 53 (1985): 1499-1528.

Tobin, James, "Asset Holdings and Spending Decisions," 1952, reprinted in Essays in Economics, vol. 1, Amsterdam: North-Holland, 1971.

Trostel, Philip A., "The Nonequivalence Between Deficits and Distortionary Taxation," Journal of Monetary Economics 31 (April 1993): 207-227. 


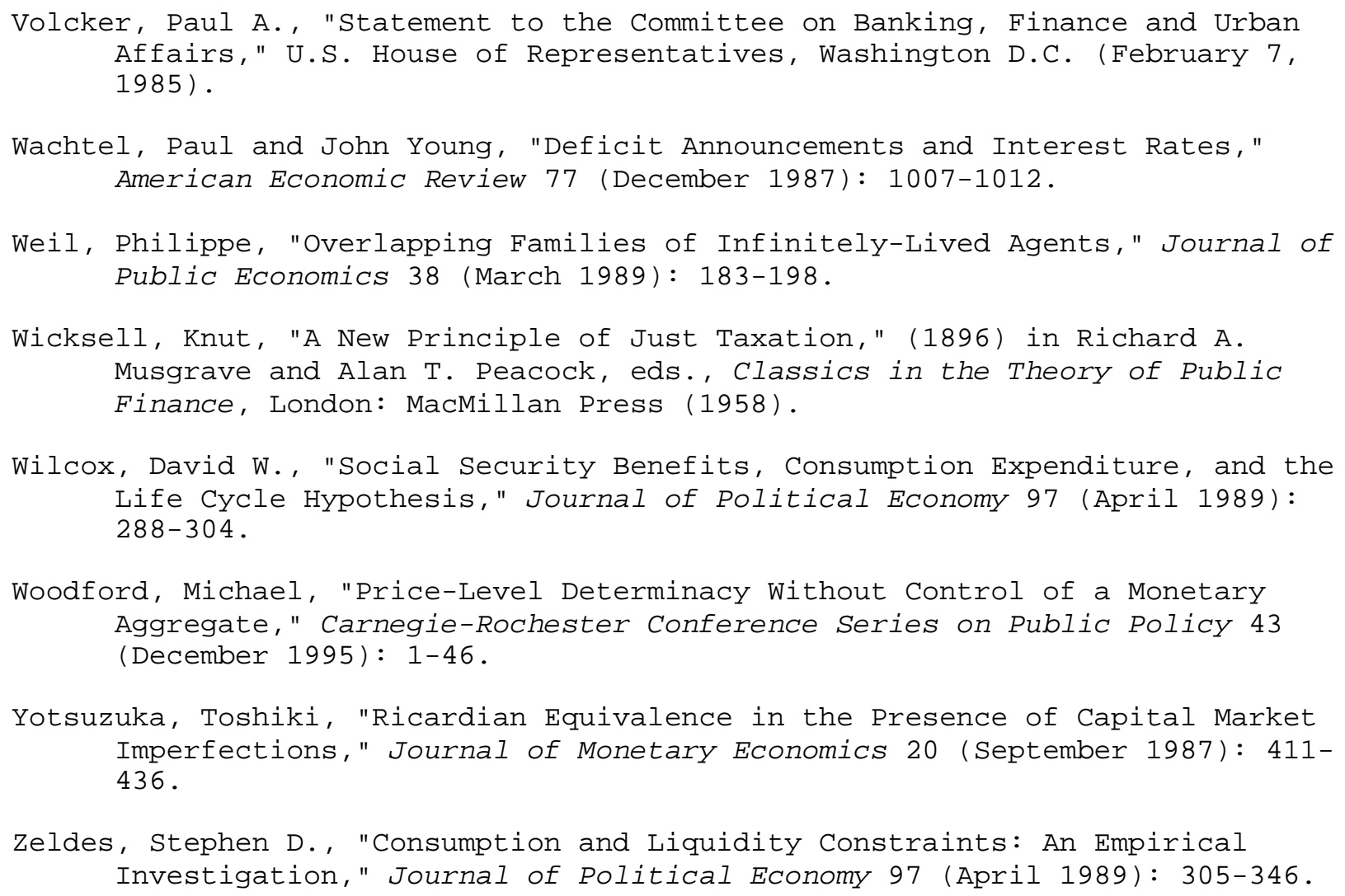


Table 1

Debt and Deficits in Industrialized Countries in 1996 (percent of GDP)

\begin{tabular}{|c|c|c|c|}
\hline Country & Net Debt & Budget Surplus & $\begin{array}{c}\text { Primary Budget } \\
\text { Surplus }\end{array}$ \\
\hline U.S. & 49 & -2 & 1 \\
\hline Japan & 14 & -4 & -4 \\
\hline Germany & 48 & -4 & -1 \\
\hline France & 39 & -4 & -1 \\
\hline Italy & 112 & -7 & 3 \\
\hline United Kingdom & 44 & -4 & -1 \\
\hline Canada & 70 & -2 & 4 \\
\hline Australia & 29 & -1 & 0 \\
\hline Austria & 51 & -4 & 0 \\
\hline Belgium & 127 & -3 & 5 \\
\hline Denmark & 46 & -2 & 1 \\
\hline Finland & -8 & -3 & -1 \\
\hline Greece & n.a. & -7 & 4 \\
\hline Iceland & 37 & -2 & 1 \\
\hline Ireland & n.a. & -1 & 3 \\
\hline Korea & -22 & 4 & 4 \\
\hline Netherlands & 48 & -2 & 2 \\
\hline New Zealand & n.a. & 3 & 4 \\
\hline Norway & -28 & 6 & 7 \\
\hline Portugal & n.a. & -4 & 1 \\
\hline Spain & 53 & -5 & 1 \\
\hline Sweden & 26 & -4 & -1 \\
\hline $\begin{array}{l}\text { TOTAL of these } \\
\text { countries }\end{array}$ & 45 & -3 & 0 \\
\hline
\end{tabular}

Note: Data are from OECD (1997, pages A33, A35, and A38) and include all levels of government. "n.a." denotes not available. 
Table 2

U.S. Federal Government Explicit Assets and Liabilities

\begin{tabular}{lc}
\hline \multicolumn{1}{c}{ Category } & $\begin{array}{c}\text { Estimated Value in } \\
\text { (\$ bilions) }\end{array}$ \\
\hline Liabilities & 3219 \\
$\quad \begin{array}{l}\text { debt held by the public } \\
\text { (excluding the Federal Reserve) } \\
\text { federal pension liabilities }\end{array}$ & 1513 \\
insurance liabilities & 66 \\
other & 498 \\
Assets & 576 \\
financial assets & 1737 \\
physical assets & 2983 \\
Net liabilities & \\
\hline Note: Data are from OMB (1996).
\end{tabular}


Table 3

Elderly Dependency Ratios

\begin{tabular}{lcc}
\hline Country & 1990 & 2030 \\
\hline Japan & 19 & 49 \\
Germany & 24 & 54 \\
France & 23 & 43 \\
Italy & 24 & 52 \\
United Kingdom & 27 & 43 \\
Canada & 19 & 44 \\
United States & 21 & 36 \\
\hline Note: Data are from CBO (1997b). & & \\
\hline
\end{tabular}


Table 4

Projected Effect of Population Aging on

Fiscal Conditions in Industrialized Countries

(percent of GDP)

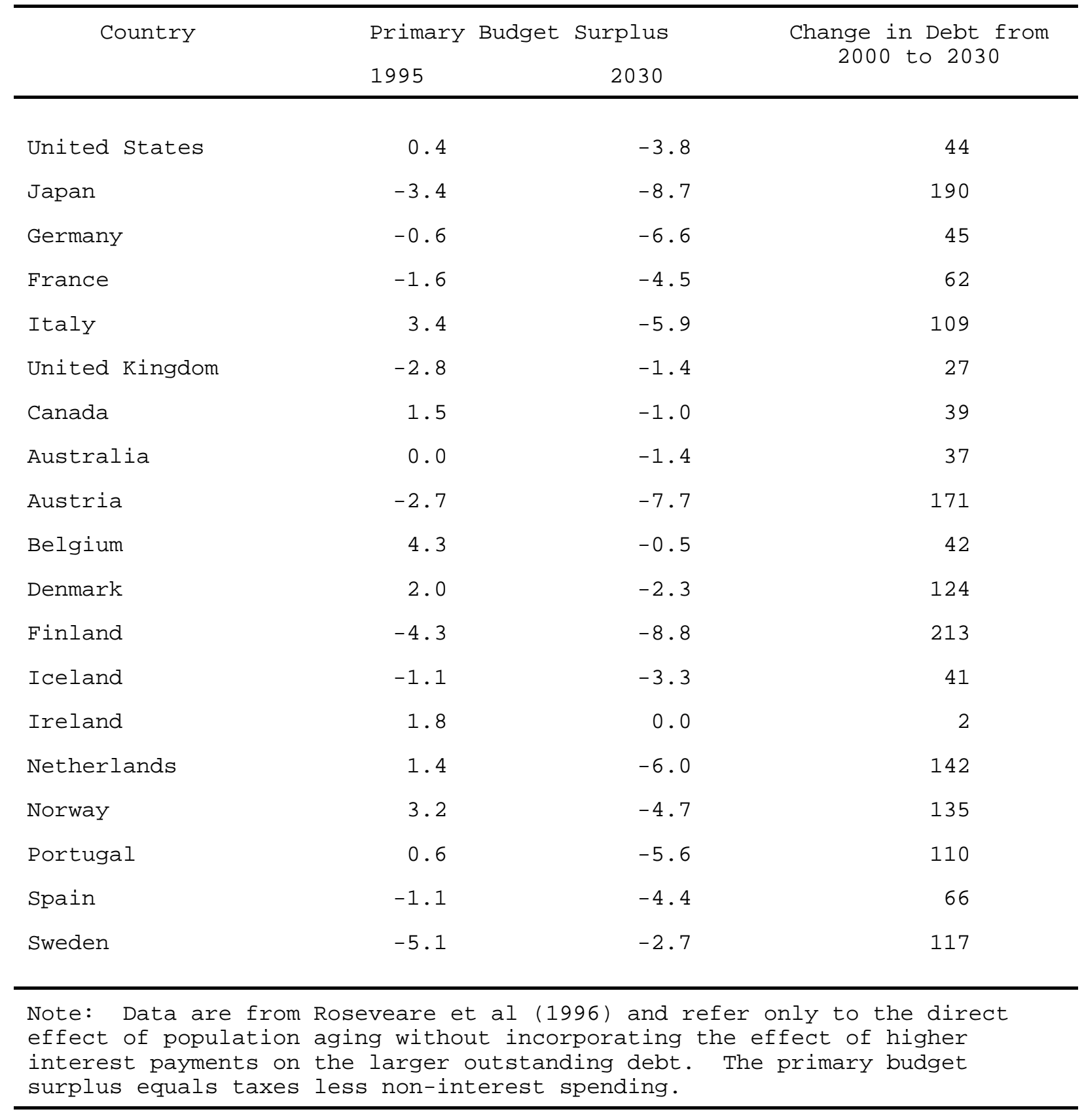


Table 5

CBO Baseline Projections for the U.S. Budget

(percent of GDP)

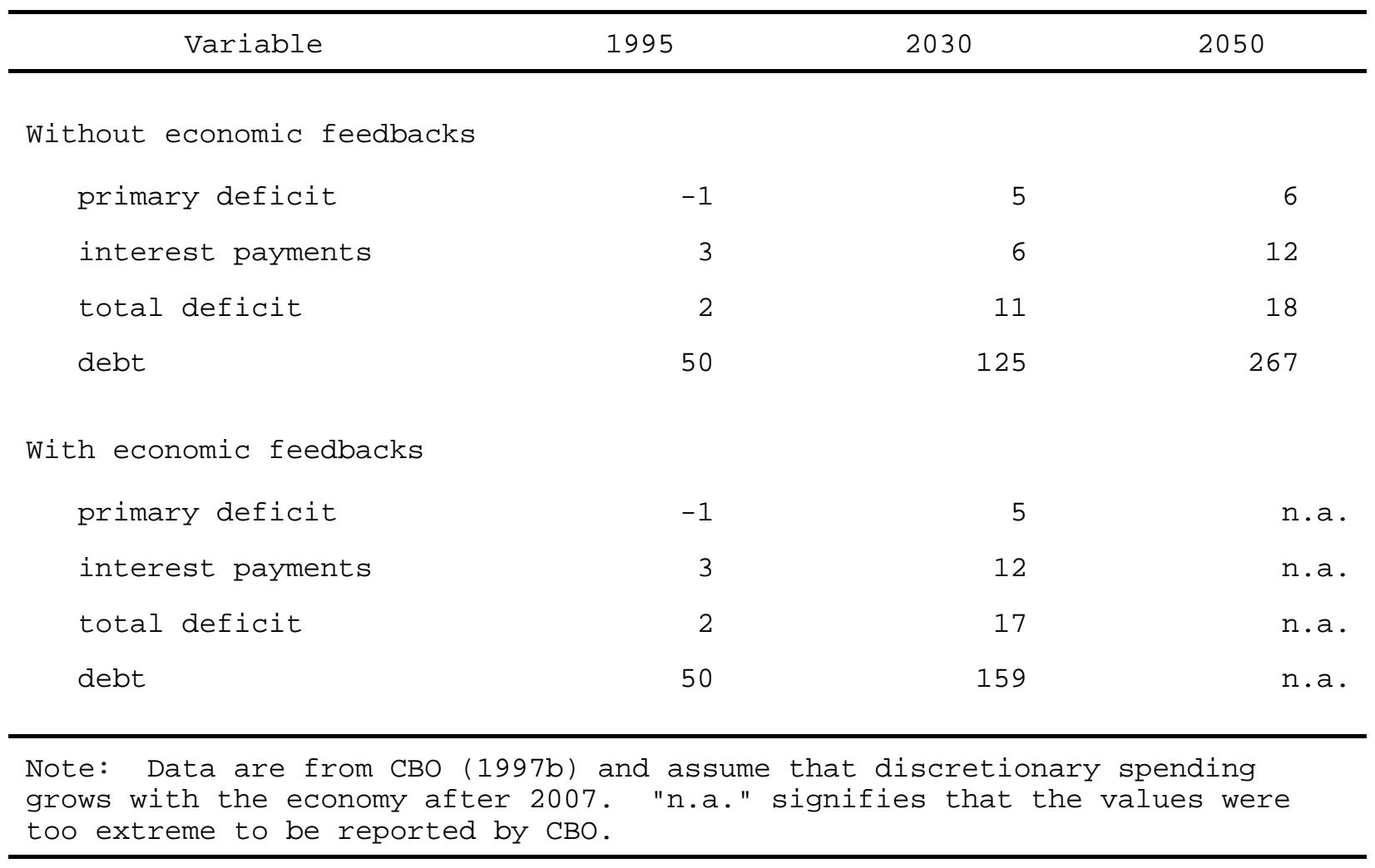

